\title{
AN ANNOTATED SPECIES LIST OF PARASITES FOUND IN EUROPEAN SMELT OSMERUS EPERLANUS (L.)
}

\author{
L. V. Anikieva, E. P. leshko \\ Institute of Biology, Karelian Research Centre, Russian Academy of Sciences, \\ Petrozavodsk, Russia
}

\begin{abstract}
This paper offers a summary of the data on parasites of European smelt based on own collections and materials published in journal reviews, scientific papers, conference proceedings and theses. The system of parasitic organisms published in Catalogues of parasites of freshwater fishes of North Asia [Pugachev, 2001-2004] is used, taking into account new studies on the systematics of infusorians and trematodes. Other groups of parasites are considered within the frameworks of widely used classifications. The species structure of European smelt and its ecological forms follow the classification by L. Berg [1948] and Yu. Reshetnikov [Atlas ..., 2003]. Altogether 65 species/taxa of parasites have been recorded from the distribution range of European smelt (Conoidasida - 1, Haplophasea 2, Ichthiosporea - 1, Myxosporidia - 1, Phyllopharyngea - 1, Oligohymenophorea 3, Monogenea - 1, Cestoda - 9, Trematoda - 11, Nematoda - 19, Palaeacanthocephala 7, Hirudinea - 1, Bivalvia - 1, Crustacea - 7). Each parasite species is briefly described; the species occurrence in different smelt ecoforms, sources for species records (provenance and author) are stated. For higher taxa, we analyzed the taxonomic diversity of smelt parasites, their zoogeographic zoning and distribution, as well as specificity, distinctive morphological, biological and ecological traits.
\end{abstract}

Ke y w o rd s: Osmerus eperlanus; smelt; parasites; species list.

\section{Л. В. Аникиева, Е. П. Иешко. АННОТИРОВАННЫЙ СПИСОК ВИДОВ ПАРАЗИТОВ ЕВРОПЕЙСКОЙ КОРЮШКИ ОSMERUS EPERLANUS (L.)}

Обобщены данные по паразитам европейской корюшки, основанные на собственных и литературных материалах, опубликованных в журнальных обзорах, научных публикациях, материалах конференций и диссертациях. В работе использована система паразитических организмов, опубликованная в Каталогах паразитов пресноводных рыб Северной Азии [Пугачев, 2001-2004], учтены новые исследования в области систематики инфузорий и трематод. Остальные группы паразитов рассмотрены в рамках широко применяемых классификаций. Структура вида европейской корюшки и ее экологические формы приняты по классификации Л. С. Берга [1948] и Ю. С. Решетникова [Атлас..., 2003]. В общей сложности в ареале европейской корюшки зарегистрировано 65 видов/таксонов паразитов (Conoidasida - 1, Haplophasea - 2, Ichthiosporea - 1, Myxosporidia - 1, Phyllopharyngea - 1, Oligohymenophorea - 3, Monogenea - 1, Cestoda - 9, Trematoda - 11, Nematoda - 19, Palaeacanthocephala - 7, Hirudinea - 1, Bivalvia - 1, Crustacea - 7). Для каждого вида дана краткая характеристика, указаны встречаемость у отдельных экологических форм корюшки, место и автор находок. В рамках высших таксонов предпринят анализ таксономического разнообразия паразитов европейской корюшки, их зоогеог- 
рафического районирования и распространения, а также характера специфичности, особенностей морфологии, биологии и экологии.

Кл юч е в ы е с л о в а: Osmerus eperlanus; европейская корюшка; паразиты; список видов.

The smelt, or European smelt is one of major harvested fish species in water bodies of the European North, a common object of sport and commercial fishing, an important food item for predaceous fish [Sterligova et al., 2016]. Smelt have a wide distribution from France (the Loire) to the Baltic, White and Barents Seas, including the south-eastern part of the Scandinavian Peninsula and south-west Ireland. The Russian distribution spans the cathments of all of these seas. The species occurs in the Kola Peninsula, is widespread in Karelia and water bodies from the Northern Dvina to the Pechora and lakes of Bolshezemelskaya tundra [Atlas..., 2003]. The smelt have dispersed widely across Northern Europe after the last deglaciation and grew adapted to a variety of ecological conditions, having differentiated into lacustrine, lacustrine-riverine and anadromous forms [Klyukanov, 1977].

In the past few decades smelt have been dispersing through lake-river systems of the European North, colonizing not just new water bodies but even new zoogeographic provinces. Smelt invasion and dispersal methods are varied: through aquacultural acclimation actions, unaided dispersal and incidental introductions. Smelt have descended from Lake Beloye to the Volga catchment, and now reside in Rybinskoye, Gorkovskoye, Kuibyshevskoye and Saratovskoye storage reservoirs [Ivanova, 1982]. Smelt have been repeatedly stocked into water bodies of Karelia to improve food resources for predaceous fish. In the 1950s, smelt larvae from Lake Onego were relocated to Lake Sundozero, where they successfully naturalized and multiplied to substantial abundances. Smelt eggs from Lake Ladoga have been stocked into lakes Segozero, Seletskoye, Maslozero, and Yelmozero. In all of these lakes smelt have turned into the main food item for pike Esox lucius, burbot Lota lota and Arctic char Salvelinus lepechini. After introductions in 1979-1985, smelt from Lake Onego have become naturalized in Verkhnetulomskoye storage reservoir (Murmansk Region, White Sea catchment) [Karasev et al., 2009]. Investigation of the process of natural dispersal and establishment of smelt populations showed the species successfully becomes naturalized in the new ecosystems, grows to harvestable abundances and turns into the main food item for predaceous fish [Karasev et al., 2009; Sterligova and IImast, 2012].
Smelt's wide ecological valence, high abundance, biomass and production values provide it with competitive advantage against native species, wherefore smelt invasions in new water bodies are fraught with negative consequences. For instance, smelt incidentally introduced to Lake Syamozero in Karelia shortly became dominant in the fish population, profoundly modifying the structure and trophic relations in the fish community [Reshetnikov et al., 1982; Sterligova et al., 2002; Kriksunov et al., 2005].

It is a known fact that biological invasions in aquatic ecosystems are closely associated with parasitological problems. Introduced fish species may bring along non-specific parasites. A notorious case is the kill of the ship sturgeon (Acipenser nudiventris) by the monogenean Nitzschia sturionis introduced with the stellate sturgeon (Acipenser stellatus) translocated from the Caspian to the Aral Sea [Lutta, 1941]. In the 1970s, Scandinavian rivers were infected with the introduced monogenean Gyrodactylus salaris. The parasite infested local Atlantic salmon populations and spread widely across 40 rivers, resulting in a catastrophic loss of salmon populations [Malmberg, 1989]. The nematode Anguillicola crassus was introduced to European waters with the transported Japanese eel, Anguilla japonica. It caused massive mortalities in the European eel, nearly wiping out its population [Molnar et al., 1994; Sures and Knopf, 2004]. The myxozoan Myxobolus cerebralis was introduced from Europe to the USA, causing mortalities among salmonids [Granath et al., 2007]. An Asian parasite Schyzocotyle acheilognathi has become one of the most widespread parasites globally [Marcogliese, 2008].

Parasite-induced epizootic events in smelt have occurred in a number of water bodies. High mortalities of smelt in lakes IImen and Seliger have been due to the myxosporidian Pleistophora ladogensis. The infection levels have been especially high in juvenile fish [Khlopina, 1920]. An epidemic in smelt caused by the myxosporidian Glugea hertwigi broke out in American Great Lakes [Nellbring, 1989]. Among the parasites acquired by the spontaneously invasive smelt in Lake Syamozero there appeared a superdominant species - the myxosporidian Glugea hertwigi. This myxosporidian infection caused massive fish kill, catch reduction and modification of the size structure of the smelt stock [leshko et al., 2000]. Heavy infection events have also been reported in 
smelt from Lake Vesijarvi (Finland), which, considering the continuing eutrophication of the lake, may lead to epizootics [Sterligova et al., 1992].

The parasite fauna of smelt has by now been quite thoroughly investigated. Many materials are, however, scattered among various publications that are not always easily accessible to parasitologists. Parasitological literature had for a long time been using one common name of 'smelt' to denote all the different forms and subspecies of Osmerus eperlanus and species of Osmeridae family. A revision of the Osmeridae family substantially changed the existing ideas about the taxonomic status of these species and their infraspecies structure, biology and distribution ranges [McAllister, 1963; Boguckaya, Naseka, 2004; Nelson, 2009], necessitating a check of the host species list and data on their geographical distribution.

The aim of this study has been to collect and summarize available published data on the species composition of parasites found in European smelt, specifying its ecoform, sampling location, author of the records, and infection rates.

\section{Materials and Methods}

The data on parasites of the European smelt are based on own and published materials collected from around the species distribution range. The species list of parasites found in European smelt is arranged in line with the system of parasitic organisms published in Catalogues of parasites of freshwater fishes of North Asia [Pugachev, 2001-2004], as well as in recent studies on the systematics of Infusoria [Lynn and Small, 2002] and Trematoda [Gibson et al., 2002; Jones et al., 2005]. The rest of parasite groups were considered within widely used classifications (cestodes - Khalil et al., 1994; nematodes - Moravec, 1994; acanthocephalans Amin, 1985, 2013). The species structure of the European smelt and its ecoforms follow the classifications of L. S. Berg [1948] and Yu. S. Reshetnikov [Atlas..., 2003].

\section{Results}

The final list of parasites recorded from European smelt contains 65 species.

Phylum of PROTISTA Haeckel 1866

Class Conoidasida Levine 1988

Eimeria osmeri Molnar, Fernando 1974

Specialist parasite of smelt. Localized in epithelial cells of intestine, liver, kidneys and other organs. Holarctic species.

Found in the lacustrine form of smelt from Lakes Ladoga, Onego and Pyaozero $(6 \%, 5 \%$ and $7 \%$, respectively) [Rumyantsev, 2007].

\section{Class Haplophasea Sprague, Becnel et} Hazard 1992

\section{Glugea hertwigi Weissenberg 1921}

Specialist parasite of smelt. Occurs widely across the host's range. Holarctic species.

Found in both anadromous and freshwater forms of smelt in lakes of Finland [Valtonen et al., 2012], Lake Ladoga [Barysheva and Bauer, 1957; Rumyantsev et al., 2001], the Neva River, lakes in the upper course of the Volga: Seliger, Beloye, Pestovo [Khlopina, 1920], the Northern Dvina [Shulman and Shulman-Albova, 1953]. Other fish known to host the parasite are vendace and whitefish. The findings from pond smelt Hypomesus olidus in the Amur and from Siberian lake whitefish need to be verified [Opredelitel'..., 1984]. Pathogenic species. Causes epidemics in smelt.

\section{Pleistophora ladogensis Voronin 1978}

Specialist parasite of smelt and burbot. $\mathrm{Pa}$ laearctic species.

Identified as Plistophora typicalis (Gurley 1893) in Lakes IImen, Seliger, Pestov [Khlopina, 1920]. Found in anadromous smelt from the Elbe estuary (19.3\%) [Sprengel and Liichtenberg, 1991; Kerstan, 1992] and in lacustrine smelt from Lakes Ladoga (19\%) and Onego [Rumyantsev, 2007]. Recorded in burbot from Lake Vrevo, Leningrad Region [Voronin, 1978]. Pathogenic species. More frequent on juvenile fish; causes epidemics in smelt.

\section{Class Ichthiosporea Cavalier-Smith 1998 \\ Dermocystidium sp.}

Representative a small group Opisthokonta within Eukarya, predominantly fish parasites.

Found in dwarf (lake) smelt (Osmerus eperlanus eperlanus $m$. spirinchus Pallas) from Lake Beloye (6.6 \%) [Radchenko, 1999]. Surveying the same lake, Radchenko [1999] recovered Dermocystidium also from perch and pike, identifying it as D. percae.

Class Myxosporidia Butschli 1881

\section{Chloromyxum coregoni Bauer 1948}

Widespread Holarctic species. Representative of the Arctic freshwater faunal complex. Parasitic in Coregonids (vendance Coregonus albula, whitefish C. lavaretus) and Atlantic salmon Salmo salar.

Found in freshwater smelt from Lake Ladoga (7\%) [Barysheva and Bauer, 1957].

\section{4}

Class Phyllopharyngea de Puytorac et al.

\section{Capriniana piscium (Butschli 1889)}

Widespread Palaearctic species. Representative of the Boreal flatland faunal complex. Occurs in a variety of fish hosts.

Found in freshwater smelt from Lakes Ladoga, Onego and Pyaozero $(6 \%, 40 \%, 47 \%$, respectively) [Rumyantsev, 2007], and recorded as Cap- 
riniana sp. (80 \%) in dwarf smelt from Lake Beloye [Radchenko, 1999].

Class Oligohymenophorea de Puytorac et al. 1974

\section{Trichodina pediculus Ehrenberg 1838}

Widespread Palaearctic species. Representative of the Boreal flatland faunal complex. Parasitic in a wide range of hosts.

Found in lacustrine smelt from Lakes Ladoga, Onego and Pyaozero $(6 \%, 5 \%, 13 \%)$ [Rumyantsev, 2007].

\section{Tripartiella copiosa Lom 1959}

Widespread Palaearctic species. Representative of the Boreal flatland faunal complex. Occurs predominantly in Cyprinids.

Found in lacustrine smelt from Lakes Ladoga, Onego and Pyaozero (31\%, $45 \%$, $33 \%$ ) [Rumyantsev, 2007].

Tripartiella lata Lom 1963

Palaearctic species. Found in minnow Phoxinus laevis, bullhead minnow Pimephales vigilax and grass carp Ctenopharyngodon idella from water bodies of the Czech Republic and Slovakia [Hoffman, 1999].

Found in lacustrine smelt in lakes of Finland [Valtonen et al., 2012].

Protozoa are taxonomically the most diverse group of smelt parasites. Eight of the species belong to 4 phyla, 6 classes, 6 orders, 6 familes, 7 genera. Dermocystidium sp. belongs to a poorly studied group parasitic on gills and skin of fish and amphibians. It used to be placed in a group of fish parasites (the "DRIP clade") of unclear systematic position. A later revision moved it into Opisthokonta - a broad group of eukaryotes including both the animal and fungus kingdoms together with the eukaryotic microorganisms that are sometimes grouped in the paraphyletic phylum Choanozoa. Genetic and ultrastructural studies have confirmed the monophyly of this taxon.

In terms of host specificity, protozoan parasites of smelt fall into 2 groups - specialists in smelt and wide generalists. Three species are specialist parasites of smelt. One of them - coccidian Eimeria osmeri, was described for the first time from rainbow smelt from Lake Ontario (Canada), and later found in European smelt from Karelian lakes. The second specialist is the myxosporidian Pleistophora ladogensis. Fish-parasitic myxosporidians have sometimes been misidentified or identified down to the genus level only. This was the case with the species Pleistophora ladogensis. Myxosporidian spores were isolated from muscles of burbot from Lake Vrevo (Leningrad Region) and identified down to the genus Plistophora [Voronin, 1978]. Later on, when myxosporidians from muscles of burbot from Lake Vrevo and smelt from Lake Ladoga were ex- amined, the shape of the spores was found to differ from all known myxosporidians of the genus Pleistophora from both marine and freshwater fish, and the new species Pleistophora ladogensis was described [Voronin, 1978]. In Lake Vrevo the parasite was found only in burbot, whereas in Lake Ladoga only in smelt. Spores retrieved from smelt and from burbot were similar in shape but with some minor distinctions: the anterior end of myxosporidian spores from smelt was narrower than in spores from burbot. The fact that smelt from Lake Vrevo was not infected and the distinctions, although minor, in the shape of spores from these two fish species, brought the author to the assumption that the species $P$. ladogensis is heterogenous, possibly comprising two subspecies [Voronin, 1978].

The third specialist in smelt is the myxosporidian Glugea hertwigi - a widespread parasite of European and rainbow smelt. The parasite has been reported from Russia and North America. Some water bodies have repeatedly experienced epizootics caused by G. hertwigi [Voigt, 1975]. A particularly heavy infection in smelt was found in American Great Lakes [Nellbring, 1989]. The spread of the myxosporidian $G$. hertwigi is most likely associated with eutrophication of Lakes Erie and Ontario, where 10 years after its first finding the parasite caused a massive smelt kill. Occasions of heavy infection in smelt have also been recorded in Lake Vesijärvi (Finland), with a risk of epizootic looming because of continuing eutrophication of the lake [Sterligova et al., 1992]. Major transformations in the structure and trophic relations in the fish community have been caused by smelt accidentally introduced into Lake Syamozero (Karelia). Among the parasites acquired by smelt in the new habitat there appeared a superdominant species - myxosporidian Glugea hertwigi. The myxosporidian infection caused massive fish kill, reducing catches and modifying the size structure of the smelt stock [leshko et al., 2000].

Five of the protozoan species have a fairly wide range of hosts. Three of the species occur the most frequently in one taxonomic group of fish: the myxosporidian Chloromyxum coregoni is a parasite of salmonoid fish (salmon, whitefish, vendace) in lakes of Karelia [Rumyantsev and leshko, 1997; Barskaya et al., 2008], Tripartiella copiosa and $T$. lata mostly parasitize cyprinids.

All protozoan species found in smelt inhabit sweet and brackish waters, have Holarctic and Palaearctic distribution. Three of the species belong to the Arctic faunal complex, 5 to the Boreal flatland complex, and two (Eimeria, Dermocystidium) are of undetermined affiliation. A majority of the species occur locally. Their abundance in smelt is usually low, limited to one or few findings. The most fre- 
quently found species in smelt from Karelian lakes is Tripartiella copiosa.

\section{Subregnum METAZOA}

Class Monogenea (Van Beneden 1858) Bychowsky 1937

Gyrodactylus osmeri Rumyantsev, Schulman \& lyeshko 1998

Specialist parasite of smelt. Palaearctic species.

Found in lacustrine smelt from Lakes Ladoga, Onego, Pyaozero (19\%, 5\%, $60 \%$ ) [Rumyantsev et al., 2001; Rumyantsev, 2007] and anadromous smelt from the Gulf of Bothnia [Valtonen et al., 2012].

Discrimination between monogenean species is admittedly a very challenging task. G. osmeri is morphometrically very similar to Gyrodactylus lavareti - a parasite of Coregonids, but its haptoral elements (hamuli, etc.) are smaller. It is also similar to G. bolonensis - a parasite of pond smelt Hypomesus olidus from Lake Bolon' (Amur River catchment), but differs in some systematic traits: shape and total length of hamuli, as well as no narrowing of hamulus root [Rumyantsev et al., 1998]. Gibson, Bray \& Harris (compilers) [2005] originally regarded Gyrodactylus osmeri as unverified. Valtonen et al. [2012] however found this species in the Gulf of Bothnia and included it in the list of smelt parasites. We have compared the dimensions of G. osmeri and Gyrodactylus lavareti and demonstrated that the two species differ not only in the size of hooks, but also in relationships between traits, first of all the ratio of whole body and opisthaptor dimensions. The data obtained confirm the validity of identifying the monogenean from smelt as a separate species $G$. osmeri. One can infer a genetic relationship between Gyrodactylus lavareti and $G$. osmeri, as well as $G$. osmeri descent from Gyrodactylus lavareti.

\section{Class Cestoda Rudolphi 1808}

\section{Triaenophorus crassus Forel 1868}

Holarctic species. Representative of the Boreal flatland complex. The definitive host is pike. Various copepods serve as the first intermediate host. The second intermediate host for $T$. crassus is salmonoid fish [Kuperman, 1973].

Found in lacustrine smelt from Lake Ladoga $7 \%$ [Barysheva and Bauer, 1957]. One plerocercoid was retrieved from muscles of each of two 0+ dwarf smelt from Lake Vozhe [Radchenko, 2002]. Rybak [1982] postulated T. crassus in smelt from Lake Segozero was the result of the parasite's invasion in the smelt stocked into the lake as eggs from Lake Ladoga.

\section{Triaenophorus nodulosus (Pallas 1781)}

Holarctic species. Representative of the Boreal flatland complex. The definitive host is pike. Various copepods serve as the first intermediate host.
Can employ many fish species as second intermediate hosts. Smelt is often among them [Kuperman, 1973].

Found in anadromous and lacustrine ecoforms from the Gulf of Bothnia, lakes of Karelia (Ladoga, Onego, Pyaozero) and Kola Peninsula (Kovdozero), in dwarf smelt from lakes of the Pskov, Tver and Vologda Regions (Chudskoye, Pskov, IImen, Beloye, Seliger). The infection prevalence in smelt varies widely among water bodies (from $1 \%$ to $93 \%)$. The intensity however is not so severe: 1-2 worms per fish, abundance index is 0.3-0.4 worms [Barysheva and Bauer, 1957; Kogteva, 1957; Mitenev and Schulman, 1999; Anikieva et al., 2016b]. The highest intensity of $T$. nodulosus infection in dwarf smelt was reported from Lake Chudskoye: 1-5 worms, an average of 2.9 [Kogteva, 1957].

\section{Eubothrium crassum (Bloch 1779)}

Widespread Holarctic species. Representative of the marine complex.

Found in anadromous smelt on the North Sea coast [Marre, 1931] and in dwarf smelt from Lake Beloye (9.9-28.4\%) [Radchenko, 1999]. The finding of $E$. crassum in dwarf smelt is questionable.

\section{Eubothrium salvelini Schrank, 1790}

Widespread Holarctic species. Representative of the Arctic faunal complex.

Found in lacustrine smelt from Lake Ladoga (27 \%) [Barysheva and Bauer, 1957], Lakes Ladoga, Onego, Pyaozero (12, 10, $20 \%$, respectively) [Rumyantsev et al., 2001; Rumyantsev, 2007].

\section{Diphyllobothrium dendriticum (Nitzsch} 1824)

Widespread Holarctic species. Representative of the Arctic faunal complex. The first intermediate host is copepods. The second intermediate and reservoir hosts are salmonoid fish, smelt, pike, osman, burbot, nine-spined and three-spined sticklebacks. The definitive hosts are piscivorous birds (gulls), red fox, Arctic fox, otter, humans [Delamure et al., 1985].

Found in anadromous smelt from the Gulf of Bothnia [Valtonen et al., 2012]. Smelt is the second intermediate and reservoir host.

\section{Diphyllobothrium ditremum (Creplin 1825)}

Widespread Holarctic species. Representative of the Arctic faunal complex. The first intermediate host is pelagic copepods of genera Eudiaptomus, Cyclops. The second intermediate and reservoir hosts are salmonoid and osmerid fish. The definitive host is piscivorous birds (gulls).

Widespread in the distribution range of smelt (Finland, Norway, Karelia, Germany: Elbe delta) [Palm et al., 1999]. In Lakes Ladoga, Onego and Pyaozero the prevalence was $12,5,7 \%$, respectively [Rumyantsev, Permyakov, 1994; Rumyantsev 
et al., 2001; Rumyantsev, 2007], in Lakes Ukshezero and Pertozero $2 \%$ [Petrushevsky and Bykhovskaya, 1933], in Lake Vygozero $16 \%$ [Anikieva, 1982], in dwarf smelt from Lake Chudskoye 13.2$46.6 \%$ with the intensity of 1 worm [Kogteva, 1957].

\section{Diphyllobothrium latum (Linnaeus 1758)}

Holarctic species. Representative of the Boreal flatland complex. The first intermediate host is pelagic copepods. The second intermediate and reservoir hosts are fish of different taxonomic groups, most often pike, burbot, perch and ruffe. Definitive hosts are mammals and humans.

Found in smelt from Lake Kovdozero (2.4\%, 0.02; Kola Peninsula) [Mitenev and Schulman, 1999] and Lake Ladoga (6 \%) [Rumyantsev, 2007].

Proteocephalus Iongicollis (Zeder 1800)

Widespread Holarctic species. Representative of the Arctic faunal complex. The first intermediate hosts are various species of copepods. Definitive hosts are salmonoid fish. Preferred hosts are planktivorous coregonids (whitefishes, vendace).

For the first time identified from smelt as $P$. exiguus and found in the Northern Dvina [Kudryavtseva, 1957]. Later on discriminated from Proteocephalus tetrastomus and found in smelt from the North Sea and Baltic Sea coasts, and Lakes Ladoga and Onego in Karelia [Willemse, 1969; Anikieva, 1998]. The prevalence in smelt from Lake Onego was $74 \%$ with an intensity of 1-69 worms and abundance index of 6.3 worms [Anikieva et al., 2016a]. In Lake Syamozero the species colonized spontaneously adventitious smelt by transfer from native hosts (whitefish and vendace) [Anikieva and leshko, 2010]. Found in lacustrine and dwarf smelt in many water bodies.

Proteocephalus tetrastomus (Rudolphi 1810)

Holarctic species. Specialist parasite of the Osmeridae family.

Widespread in smelt from the North Sea and Baltic Sea coasts [Marre 1931; Willemse, 1969]. Identified in the Elbe delta as Proteocephalus Iongicollis (Rudolphi 1802) [Jarling, 1982; Palm et al., 1999]. Found in large oligotrophic lakes in Karelia (Ladoga and Onego) [Anikieva, 1998] and in Lake Goluboye in the eastern periphery of the European smelt's distribution range. The prevalence of $P$. tetrastomus infection in smelt from Lake Ladoga was $13.3 \%$, the intensity was 1-3 worms, abundance index 1.3 worms; in Lake Goluboye the prevalence was $100 \%$, intensity from 2 to 283 worms, abundance index 39.9 worms [Anikieva and Dorovskikh, 2009].

Taxonomically, smelt-parasitizing cestodes constitute a relatively compact group of species. Three cestode species belong to the genus Diphyllobothrium. The predominantly salmonoid-hosted parasites Diphyllobothrium dendriticum and D. di- tremum are sympatric. The key morphological traits for discriminating between these two Diphyllobothrium species are scolex morphology, body size and shape. The prevalence and abundance of $D$. ditremum in planktivorous fish is higher compared to $D$. dendriticum, but predaceous fish are more intensively infected with $D$. dendriticum than with $D$. ditremum. The preferred and typical host for $D$. ditremum in northern waters is vendace. The species abundance is, however, usually low [Anikieva and Rumyantsev, 2005].

In West Siberia, D. dendriticum has caused a disease, diphyllobothriasis, in humans. Plerocercoids of the genus Diphyllobothrium in smelt were described by von Linstow in 1878 under the name of Bothriocephalus osmeri. The close similarity between Diphyllobothrium osmeri and Diphyllobothrium ditremum was remarked by Vik [1962], who supposed they were identical. Bylund [1975] proved that $D$. osmeri is synonymous with $D$. ditremum. D. ditremum was found in smelt from Karelian lakes, in Finland, in Norway [Delamure et al., 1985]. Palm et al. [1999] listed Diphyllobothrium osmeri among parasites of smelt from the Baltic Sea and the North Sea catchments. D. latum plerocercoids mainly occur in perch, ruffe, burbot and pike. In smelt $D$. latum has been recorded as an incidental or rare species.

It has now been established that Eubothrium crassum comprises three races (one freshwater and two marine), which differ in distribution, specialization and biology. The main host for the freshwater race is brown trout Salmo trutta inhabiting European waters. The Atlantic (marine) race occurs in the North Atlantic in salmon Salmo salar, and the Pacific (also marine) race - in Oncorhynchus spp. Hanzelova et al. [2005] compared the principal morphometric traits of Eubothrium crassum from trout, E. salvelini from stone loach, and cestodes of the genus Eubothrium from vendace, and found that cestodes from vendace were morphologically more similar to Eubothrium crassum from trout than to $E$. salvelini from stone loach. Plerocercoids of the genus Eubothrium retrieved from smelt are more often identified as E. salvelini. There are several reasons to doubt the finding of $E$. crassum in dwarf smelt from Lake Beloye. For this lake E. crassum has been reported also from Volga pike-perch (Stizostedion volgensis) - a species of the family Percidae, genus Sander. Identification of larval stages of genus Eubothrium cestodes to species is complicated by the lack of reliable discriminating traits. The life cycle of $E$. crassum can take two alternative paths. The first one involves two intermediate hosts (the first intermediate host is copepods, the second one is vendace), and the second path is with one intermediate host. In the latter 
case, the parasite's plerocercoid and adult stages are combined within one host species (vendace) [Kuperman, 1979; Anikieva et al., 2016b]. Since the only suitable definitive host for $E$. crassum in Lake Beloye is vendace, and the parasite has not been detected in this fish species, plerocercoids of the genus Eubothrium found in dwarf smelt and Volga pike-perch from this lake should rather be reported as parasites not identified down to species.

The systematics of cestodes of the genus Proteocephalus remains complicated in spite of the great many studies available on the subject. Proteocephalids from smelt have been described in different sources under different names or identified as parasites of coregonids and thymallids, wherefore species boundaries became fuzzy, and the list of hosts and the data on the geographical distribution of species required further verification [Freze, 1965]. Willemse [1969] was the first to find that smelt in the Netherlands can be co-parasitized by two morphologically distinct species. One of them is a specialist parasite of smelt $P$. tetrastomus (Rudolphi 1810). The other one is a parasite of salmonoid fish P. longicollis (Zeder 1800). Later on, both species were isolated from European smelt from the Baltic Sea drainage basin (Gulf of Bothnia, Lakes Ladoga and Onego) [Anikieva, 1998]. The host-specific groupings of $P$. longicollis from smelt and from coregonids (vendace and whitefish) were shown to differ in some parameters of morphological traits (dimension of scolex, suckers and mature proglottids) [Anikieva and leshko, 2010]. In Lake Onego the parameters of $P$. longicollis in smelt and vendace are similar. The study of the population biology of $P$. longicollis in these two host species in Lake Onego, however, revealed differences in seasonal abundance variations, size-age structure, and ratio of pre-reproductive and reproductive stages during the helminth's maturation [Anikieva et al., 2016b].

$P$. tetrastomus is the only cestode species that is specialist parasite of European smelt. Contemporary diagnosis of the species $P$. tetrastomus is based on reference material from the Netherlands. The key indicator traits of $P$. tetrastomus are trapeziform proglottids; immature proglottids are short and very wide, craspedote; apical sucker is reduced. Research into within-species variability of $P$. tetrastomus revealed heteromorphism in the species and the existence of infraspecies forms that have no taxonomic status of their own [Anikieva and Dorovskikh, 2009]. A parasite of Osmeridae $P$. tetrastomus is a fifth species of the genus Proteocephalus with Circumboreal (Holarctic) distribution [Scholz and Hanzelova, 1998]. Compared to other species of the genus Proteocephalus ( $P$. torulosus, $P$. longicollis, $P$. percae) the smelt parasite $P$. tetrastomus has fewer polymorphic traits and their variations. It is also noted for a narrower range of variation in morphometric, meristic and descriptive characters [Anikieva and Dorovskikh, 2009]. The prevalence of the infection in smelt was the highest in coastal waters of the North Sea (Netherlands) and the Baltic Sea [Willemse, 1969]. Speaking of northern freshwater ecosystems, the parasite was found in smelt only in the large oligotrophic lakes Ladoga and Onego, and the infection intensity was low [Anikieva, 1998]. The cestode $P$. tetrastomus was found also in Lake Goluboye (Pechora River catchment) in the northeastern periphery of the European smelt's distribution range. $P$. tetrastomus was found also in Japanese smelt Hypomesus transpacificus nipponensis from Lake Suwa, Japan, and in rainbow smelt Osmerus mordax from the Gulf of St. Lawrence, Canada [Scholz et al., 2004].

Smelt is the definitive host only for two cestode species belonging to the genus Proteocephalus. For a majority of cestode species ( 7 out of 9 ) smelt is the intermediate and reservoir host. The most widespread among them is the cestode Triaenophorus nodulosus, whose larvae occur in a wide range of hosts. In Lake Onego known hosts for Triaenophorus nodulosus are salmon, grayling, smelt, ide, burbot, pike-perch, perch, ruffe [Rumyantsev and leshko, 1997]. The preferred intermediate hosts for T. nodulosus in Lake Onego are perch and ruffe who, together with roach, are the main food items for pike, who stick to shallow waters near the shore. Pike begin to feed on smelt when the latter move in for spawning. The similar rates of $T$. nodulosus infection in smelt and perch (respectively 40 and $53 \%$, abundance index 0.4 and 0.8 worms) indicate that smelt can, like perch, also be a major intermediate host for the cestode. Keeping in mind, however, that smelt mostly live in pelagic parts of the lake and the spawning period is relatively short ( 2 weeks), smelt's contribution to the transmission of the infection to the definitive host (pike) is minor compared to that of perch [Anikieva et al., 2016a]. The other species of this genus, cestode $T$. crassus, is a widespread parasite found primarily in coregonids as second intermediate hosts. It rarely occurs in smelt.

One of the central ecological factors for infestation of smelt with cestodes is the dietary preferences and ration. Parasites cannot fulfill their complex life cycles without close and reliable trophic links between definitive and intermediate hosts. For instance, smelt in Lakes Ladoga and Onego are quite heavily infected with Triaenophorus nodulosus plerocercoids, and regarded as the principal intermediate host, whereas the related dwarf smelt from Rybinskoye and Sheksninskoye storage reservoirs, 
Lakes Beloye and Vozhe do not host this parasite [Kuperman, 1979; Radchenko, 1999, 2002].

All cestodes retrieved from smelt represent freshwater species widely distributed in northern Holarctic waters. They have a complex life cycle. The first intermediate host is copepods. Many cestode species can use the same crustacean species as the first intermediate host. Their role in the life cycle of the same worm species may vary among water bodies in connection with characteristics of the water body, abundance and biology of specific copepod species [Kuperman, 1979; Anikieva et al., 1983]. Two species, T. nodulosus and D. latum, belong to the Boreal flatland faunal complex, and $P$. tetrastomus has a discontinuous range, occurs in Japanese and American smelt, and in our opinion also belongs to the Boreal flatland faunal complex.

\section{Class Trematoda Rudolphi 1808}

\section{Bucephalus polymorphus Baer 1827}

Localized in gill tissues and under the skin in many cyprinids. Widespread in Palaearctic waters. First intermediate hosts are freshwater mollusks of genera Unio, Anodonta and Dreissena. Second intermediate hosts are mainly cyprinids. Definitive hosts are predaceous freshwater fish.

Found in lacustrine smelt from Lake Ukshezero $(6.6 \%)$ and dwarf smelt from Lake Chudskoye (20\%) [Petrushevsky and Bykhovskaya-Pavlovskaya, 1935; Kogteva, 1957].

Brachyphallus crenatus (Rudolphi 1802) Odhner 1905

Widespread species in Holarctic waters. Hosts marine fish of various families and orders. The main importer of the parasite to freshwater is salmonids.

Found in anadromous smelt from the Elbe estuary [Jarling, 1981, 1982].

\section{Diplostomum baeri Dubois 1937 s. Iato}

Metacercariae parasitize a wide range of host fish. Widespread species in Holarctic waters. Representative of the Boreal flatland complex.

Found in lacustrine smelt from Lake Ladoga [Rumyantsev, 2007], in dwarf smelt from Lake Beloye [Radchenko, 2002]. Widespread in the distribution range of smelt.

Diplostomum spathaceum (Rudolphi 1819) Braun 1893.

Eye lens. Palaearctic species. Representative of the Boreal flatland complex. Widespread parasite of many fish species, chiefly cyprinids, as well as percids.

Widespread in the distribution range of smelt. Found in lacustrine smelt from Lake Ukshezero $(92.4 \%)$ [Petrushevsky and Bykhovskaya-Pavlovskaya, 1935], Lake Ladoga (7-27 \%) [Barysheva and Bauer, 1957], Lakes Ladoga, Onego, Pyaozero (56 \%, $15 \%, 13 \%$ ) [Rumyantsev, 2007], the Northern Dvina [after Dorovskikh, 2002]. Found in anadromous smelt from the Elbe estuary [Jarling, 1981, 1982], Wadden Sea (North Sea) [Anders and Möller, 1991].

Tylodelphys clavata (Nordmann 1832) Diesing 1850

Vitreous body. Widespread Palaearctic species. Representative of the Boreal flatland complex. Occurs in a wide range of hosts, in Lakes of Karelia most often in perch, ruffe, burbot, pike, roach, whitefish [Rumyantsev and leshko, 1997].

Found in lacustrine smelt from Lake Ukshezero (6.6 \%) [Petrushevsky and Bykhovskaya-Pavlovskaya, 1935], Lakes Ladoga, Onego, Pyaozero (6 \%, ,$+ 20 \%$ [Rumyantsev, 2007], lakes of Finland [Valtonen et al., 2012].

Ichthyocotylurus erraticus (Rudolphi 1809)

On heart and in kidneys. Widespread species in Holarctic waters. Representative of the Arctic faunal complex. In most published sources, metacercariae of this species were identified as Cotylurus erraticus (Rudolphi 1809) or Tetracotyle intermedia Hughes 1928. The first intermediate hosts are mollusks Physa lewisi and Valvata helicoidae. The second intermediate hosts are coregonids, salmonids, thymallids, osmerids, and some other fish. Definitive hosts are loons (divers), gulls and terns.

Widespread in the distribution range of freshwater smelt: in lacustrine smelt from Ladoga (27\%) [Barysheva and Bauer, 1957], the Northern Dvina [Kudryavtseva, 1957], Imandra (100\%, M -19.8), Kovdozero (12.3\%, M -0.1), Kolvitskoye (86.6\%, M -6.6) [Mitenev, Schulman, 1999], Chudskoye (100\%; 73.3 \%) [Kogteva, 1957], Lakes Ladoga, Onego, Pyaozero (19\%, $35 \%, 27 \%$ ) [Rumyantsev, 2007], dwarf smelt from Lake Beloye and Lake Vozhe [Radchenko, 1999, 2002].

Ichthyocotylurus pileatus (Rudolphi 1802)

Widespread species in Holarctic waters. Swimbladder wall. Occurs in many species of cyprinids, percids, coregonids, cottids, in pike, burbot, catfish, three-spined stickleback.

Found in lacustrine smelt from Lake Ukshezero (79.2\%) [Petrushevsky and Bykhovskaya-Pavlovskaya, 1935], Lake Vygozero (16 \%) [Anikieva, 1982], in dwarf smelt from Lake Beloye (0.99\%, 3 specimens, Al 0.03) [Radchenko, 1999].

Ichthyocotylurus variegatus (Creplin 1825).

Kidneys, swimbladder wall, other organs. Widespread species in Palaearctic waters. The first intermediate host is the mollusk Valvata piscinalis. The second intermediate hosts are percids, cyprinids, and some other freshwater fish. Definitive hosts are gulls and terns.

Found in dwarf smelt from Lake Beloye (4\%) and Lake Vozhe (87.2 \%) [Radchenko, 1999, 2002].

Bunodera luciopercae (Müller 1776)

Widespread species in Holarctic waters. Representative of the Boreal flatland complex. 
The first intermediate host is mollusks Sphaerium rivicola. The second intermediate hosts are crustaceans Copepoda. Definitive hosts are predaceous fish, but found the most often in perch.

Found in smelt from lakes of Finland [Valtonen et al., 2012].

\section{Phyllodistomum umblae (Fabricius 1780)}

Urinary bladder and kidneys. Representative of the Boreal submontane faunal complex. Specialist parasite of salmonoid fish (vendace, whitefish). Widespread Holarctic species. The first intermediate hosts are mollusks Sphaerium corneum, S. capiduliferum, Lacustrina dilatata, Euglesa sp., and Sphaerium rectidens. After leaving the clams, cercariae attach themselves to the substrate and perform spinning movements. Sphaeriid clams were also found to host metacercariae at an early stage of encystment, with all traits of gorgoderids. Definitive hosts - salmonoid fish, most likely get infested either directly, by ingesting cercariae, or when feeding on clams and chironomids bearing encysted metacercariae.

Reported for dwarf smelt from Lake Beloye (20.8-40.9\%, mean intensity $2.8-5$ specimens) as Ph. conostomum.

\section{Cryptocotyle lingua (Creplin 1825)}

Skin. Holarctic species. Definitive hosts are piscivorous birds and mammals.

Found in anadromous smelt from the Wadden Sea (North Sea) [Anders and Möller, 1991].

None of the trematode species are smelt specialists. Nine of the eleven reported species belong to the freshwater ecological group of parasites. Diplostomum baeri, Diplostomum spathaceum, Tylodelphys clavata are widespread generalist parasites, the rest are mainly associated with cyprinids and percids (Buchephalus polymorphus, Ichthyocotylurus pileatus, Ichthyocotylurus variegatus), percids (Bunodera luciopercae), salmonoids (Ichthyocotylurus erraticus, Phyllodistomum umblae). Two families (Diplostomatidae, Strigeidae) include 4 species of metacercariae that actively invade fish at the cercarial stage. For 7 trematode species smelt is an intermediate and reservoir host. It is not known whether Phyllodistomum conostomum and Bunodera luciopercae develop to maturity in smelt. The most widespread in smelt's range and the most frequently occurring are two species - Diplostomum spathaceum and Ichthyocotylurus erraticus. Two other species (Bunodera luciopercae and Phyllodistomum umblae) are rare parasites. One species (Ichthyocotylurus erraticus) belongs to the Arctic faunal complex, one to the Boreal submontane (Phyllodistomum umblae - a very rare species, its species identity in smelt needs to be verified), 7 species to the Boreal flatland complex.
Brachyphallus crenatus and Cryptocotyle lingua belong to the marine ecological group and occur in a wide range of hosts. When studying the parasite fauna of fish in the White Sea, Schulman and Schulman-Albova [1953] discovered $\mathrm{Br}$. crenatus in fifteen fish species. The heaviest infections with this parasite were found in Atlantic salmon, brown trout, herring, i. e. sea-going (migrating to pelagic areas) species and, sometimes, lamprey. Fish sticking to coastal waters are almost free of the infection. In the North Sea drainage basin Br. crenatus was reported from 20 host species, including freshwater species (perch, eel, pike-perch). Cryptocotyle lingua was found in 15 fish species. For Brachyphallus crenatus smelt is a definitive host, for Cryptocotyle lingua - intermediate host. According to some data, $C$. lingua can infest mammals and humans.

\section{Class Nematoda Rudolphi 1808}

\section{Pseudocapillaria salvelini (Poljansky 1952)}

Mainly parasitizes salmonoid fish. Holarctic species. Representative of the Boreal submontane faunal complex. Paratenic hosts are oligochaetes.

Found in lacustrine smelt from Lake Ladoga [Rumyantsev et al., 2001] and Lake Onego (12\% and $10 \%$ ) [Rumyantsev, 2007].

\section{Pseudocapillaria tomentosa (Dujar-} din 1843)

Mainly parasitizes cyprinid fish. Holarctic species. Occurs at temperate and southern latitudes. The life cycle of $P$. tomentosa is probably direct, without an intermediate host, but freshwater oligochaetes may play a role of paratenic hosts [Moravec, 1994].

Found in lacustrine smelt from Lake Onego [Rumyantsev et al., 2001].

\section{Raphidascaris acus (Bloch 1779)}

Stomach parasite infecting pike (obligate host), percids, salmonids, and other predaceous fish (facultative hosts). Widespread Holarctic species. Representative of the Boreal flatland faunal complex. The life cycle of this species is one of the beststudied. Larvae emerged from eggs in water or still unhatched are ingested by intermediate hosts (fish) or paratenic hosts (invertebrates). Larvae of this nematode successfully infest quite a number of invertebrate hosts: oligochaetes of families Naididae, Tubificidae, Glossoscolecidae, Lumbriculidae and Lumbricidae; Planorbidae and Lymnaeidae mollusks; planktonic and benthic crustaceans Cyclopidae, Calanoidae, Mysidae, Gammaridae, Asellidae, Daphniidae; larvae of water insects Diptera (Chironomidae and Ceratopogonidae), and Trichoptera. Obligate intermediate hosts are fish.

Widespread in freshwater forms of smelt. Lakes Ladoga, Onego, Pyaozero (12\%, $25 \%, 13 \%$ ) [Rumyantsev, 2007], Lake Beloye (1.7\%, M 0.06) 
[Radchenko, 1999], Kola Peninsula [Mitenev and Schulman, 1999].

\section{Camallanus lacustris (Zoega 1776)}

Widespread in Palaearctic waters. Representative of the Boreal flatland faunal complex. Definitive hosts are fish of the family Percidae. The species features post-cyclic transmission.

Found in anadromous and freshwater forms of smelt in lakes of Finland - Pyhäjärvi (19.4 \%) [Voigt, 1975], Gulf of Bothnia [Valtonen et al., 2012], Lake Chudskoye (6.6\%) [Kogteva, 1957], lakes of the Kola Peninsula [Mitenev, Schulman, 1999], Lake Onego (35\%, M 1.4) [Rumyantsev, 2007], Lake Beloye (4-20 \%, M 0.1), Lake Vozhe [Radchenko, 1999, 2002], Lake Vygozero (7\%, M 0.1) [Rybak, 1982].

\section{Camallanus truncatus (Rudolphi 1814)}

Widespread in Palaearctic waters. Representative of the Boreal flatland faunal complex. Occurs in a wide range of hosts, but mainly in percids. The life cycle may involve cyprinids as reservoir hosts. Definitive hosts - predaceous fish, can be infested both via infected Cyclopoida, and when feeding on reservoir hosts.

Found in anadromous and freshwater forms of smelt from Lakes Ladoga and Onego $(6 \%,+)[R u-$ myantsev et al., 2001], Lake Beloye (1.7-3.1\%, M 0.03) [Radchenko, 1999], the Elbe River [Jarling, 1982].

\section{Philonema sibirica (Bauer 1946)}

Body cavity parasite. Probably Holarctic species. Widespread in Northern Asia. The life cycle of $P h$. sibirica is linked to coregonids, who are the nematode's definitive hosts. The first intermediate hosts are copepods Acanthocyclops sp., Eucyclops sp., Cyclops scutifer, Heterocope borealis [after Pugachev, 2004].

Found in smelt from Lake Imandra (Kola Peninsula) [Mitenev, 1997].

\section{Cystidicola farionis Fischer 1798}

Parasite of salmonoid fish. Holarctic species. Representative of the Arctic freshwater faunal complex. The first intermediate hosts are amphipods.

Found in anadromous and freshwater forms of smelt from: the Northern Dvina River [Dorovskikh, 2002], Gulf of Bothnia, Finland [Valtonen et al., 2012], Lakes Ladoga, Onego, Pyaozero (6\%, +, $67 \%$ ) [Rumyantsev, 2007], Lake Vygozero [Rybak, 1982], Lake Vozhe (0.6\%, M 0.01) [Radchenko, 2002], German coast of the North Sea [Palm et al., 1999].

\section{2)}

Sterliadochona ephemeridarum (Linstow

Widespread Holarctic species. Representative of the Boreal submontane faunal complex. Parasite of salmonoid fish.

Found in smelt from Lake Pyaozero (7\%) [Rumyantsev, 2007].
Porrocaecum spp. Larva III. Collective group

In body cavity and on serosa of internal organs. Holarctic species. At adult stages parasitize the digestive tract of birds, less often reptiles; larvae infest birds, mammals, reptiles, freshwater and marine fish. Fish serve as either second intermediate or reservoir host.

Found in anadromous smelt from the North Sea coast: 16-50 \% [Kahl, 1936; Palm et al., 1999].

Anisakis simplex (Rudolphi 1809) s. lato

Employs a wide range of intermediate, paratenic and definitive hosts and has a wide geographical distribution. Occurs in crustaceans, squids, fish and marine mammals in oceans and seas from tropical regions to the Arctic and the Antarctic. Definitive hosts are marine mammals such as whales, porpoises and seals. Fish and squids are paratenic hosts for the nematode. The species has important medical implications. Can cause severe allergies in humans.

Reported for anadromous smelt from the Elbe estuary with an intensity of $0.02-0.9 \%$ [Kerstan, 1992].

\section{Spinitectus sp.}

Parasites of aquatic and terrestrial vertebrates. At the larval stage parasitize invertebrates. Only one species of this genus, $S$. inermis, occurs within the distribution range of European smelt. It was reported from eel from the Baltic Sea drainage basin.

Found in anadromous smelt in different parts of the North Sea coast [Obiekezie et al., 1992; Palm et al., 1999].

Hysterothylacium aduncum (Rudolphi 1802)

Mainly parasitizes marine fish (clupeids, gadids, cottids, etc.). A massively occurring parasite species in the World Ocean and its seas. Adult nematodes parasitize the digestive tract of marine and anadromous fish, who can carry them to fresh waters. Larvae become encapsulated in the abdominal cavity and serosa of internal organs of fish. Infest freshwater fish entering brackish sea areas. Employ a wide range of hosts.

Found in anadromous smelt from the Daugava estuary (13.3\%, M 2), Gulf of Riga (33.3 \%, M 1.6) [Kirjušina and Vismanis, 2007] and the Elbe estuary [Jarling, 1982; Kerstan, 1992]. Reported from smelt from a bay of the Hel Peninsula (Baltic Sea, Poland) as Contracoecum aduncum. Smelt is an intermediate and reservoir host.

Hysterothylacium cf. cornutum (Stossich 1904)

Specialist parasite of the genus Thunnus. Occurs wherever there are tuna fish, including both sides of the North Atlantic, Mediterranean and Baltic Seas, northern and southern Pacific.

Found in anadromous smelt from river estuaries on the German coast of the North Sea: Eider es- 
tuary, Elbe estuary, Ems estuary, Süderaue, Weser estuary [Palm et al., 1999].

Pseudoterranova decipiens (Krabbe 1868)

The first intermediate hosts are amphipods Gammarus lawrencianus and Unciyla irrorata, as well as mysids and isopods. Fish are the second intermediate hosts for the nematode. Definitive hosts are marine mammals.

Widespread parasite of anadromous smelt in the North Sea. Smelt is the preferred second intermediate host for the nematode [Kuhn et al., 2013]. Mean prevalence in smelt was $47.3 \%$, mean intensity 2.3 specimens. Infection prevalence was $10 \%$ in smelt larvae, $36 \%$ in overwintered young-ofthe-year, $73 \%$ in adults. In $10 \%$ of adult fish nematode larvae were degenerated. Although in some regions the prevalence of fish infection with this widespread parasite can be high, there are usually few nematode specimens per fish [Möller and Klatt, 1988, 1990].

Contracaecum osculatum (Rudolphi 1802)

Holarctic species belonging to the marine ecological grouping of parasites. Parasite of marine mammals. Fish are second intermediate or reservoir hosts.

Found in anadromous smelt from Finnish water bodies [Valtonen et al., 2012].

\section{Eustrongylides mergorum (Rudolphi 1809)}

Widespread species in the Palaearctic region. Adults occur in birds from the Danube to Kamchatka. The life cycle is poorly known. Probable first intermediate hosts are oligochaetes. Fish serve as either obligate second intermediate hosts or paratenic hosts. Definitive hosts are waterbirds of different orders. Known also from Japanese water bodies.

Found in anadromous smelt from the Gulf of Bothnia [Valtonen et al., 2012].

\section{Cosmocephalus obvelatus (Creplin 1825)}

Esophagus and stomach parasite of piscivorous birds (gulls). Type species of its genus. Widespread parasite of gulls. Exceptional findings reported from mammals.Location in host: body cavity.

Found in anadromous smelt from the North Sea coast (the Elbe, etc.) [Obiekezie et al., 1992; Palm et al., 1999].

\section{Paracuaria tridentate (Linstow 1877)}

Stomach wall, mesentery. Definitive hosts are piscivorous birds (gulls).

Found in anadromous smelt from the North Sea coast (the Elbe, etc.) [Obiekezie et al., 1992].

Anguillicoloides crassus Kuwahra, Niimi, Itagaki 1974

Swimbladders of eels. It is a natural parasite of the Japanese eel in its native range. Appears to spread easily among eel populations after intro- duction to a body of water. It is considered to be one of the threats to the sustainability of populations of European eel (Anguilla anguilla). It was introduced to the European continent in the 1980s, where it was reported independently from Germany and Italy in 1982, having probably been introduced from Taiwan. It is thought to have reached England in 1987 from continental Europe. The life cycle of Anguillicoloides crassus begins when the adult nematode releases thousands of eggs in the eel's swimbladder. The eggs pass through the eel's digestive tract and the larvae emerge in the water and settle onto the substrate. They are ingested by their intermediate host, which is often a copepod or other crustacean but may also be a fish. The nematode larva reaches its infective stage within this intermediate host. The host is eaten by an eel, and the nematode finds its way from the eel's digestive tract to its swimbladder. An eel with an advanced parasite load shows symptoms such as bleeding lesions and swimbladder collapse. The eel becomes more susceptible to disease, its rate of growth slows down, and if the infestation is severe enough, it may die. Since the swimbladder is the buoyant organ which allows the eel to swim, a severe parasite infestation can hamper its ability to reach its spawning grounds.

Found in anadromous smelt from the Elbe River [Hartmann, 1994].

Of the 19 nematode species found in European smelt 13 species belong to the marine ecological grouping. Identification of larval stages of marine nematode species is complicated by the small number of morphological characters. Molecular studies have shown that many species in this group of nematodes are collective species. One of the largest families of parasitic nematodes is Anisakidae. More than a half of all members of the order Ascaridida are comprised within this family. Its taxonomic composition, however, has not yet been fully investigated. Evidence of that are recent publications with descriptions of new species. Smelt is a potential host for at least 6 genera of this family. For marine species of this parasite group, fish (including smelt) act as intermediate and reservoir hosts. Larvae become encysted in fish muscles or body cavity. Definitive hosts are marine mammals (seals) and birds. Particularly noteworthy is the parasitism of anisakid nematode larvae in smelt. Infection of humans with anisakid nematodes has happened in many countries around the world. Members of genera Anisakis, Contracaecum, Goezia, Hysterothylacium, Porrocaecum, Pseudoterranova, Raphidascaris are pathogenic for humans, fish and animals, and have medicinal and economic implications.

Seven nematode species belong to the freshwater ecological grouping of parasites. Smelt 
can be a definitive host for freshwater species (Pseudocapillaria tomentosa, Pseudocapillaria salvelini, Cystidicola farionis, Sterliadochona ephemeridarum), but the development of freshwater nematode species in smelt has not been studied. For a broad genelist parasite Raphidascaris acus and nematodes of the genus Camallanus (Camallanus lacustris, Camallanus truncatus) smelt probably serves as a reservoir host. The most frequent species of nematodes in smelt are Camallanus lacustris and Pseudoterranova decipiens.

Nematodes found in smelt belong to 4 faunal complexes. The Boreal flatland complex is represented by three species (Raphidascaris acus, Camallanus lacustris, Camallanus truncatus), the Boreal submontane complex by two species (Pseudocapillaria salvelini, Cystidicoloides tenuissima), the Arctic complex by two species (Cystidicola farionis, Philonema sibirica), and the rest of the species belong to the marine faunal complex.

\section{Class Palaeacanthocephala Meyer 1931 \\ Pseudoechinorhynchus borealis (Lin- stow 1901)}

Lives in fresh and brackish waters of the $\mathrm{Pa}$ laearctic region. Intermediate hosts are amphipods Gammarus pulex L., Pallaseopsis quadrispinosa and Monoporeia affinis [Wayland et al., 2013]. Morphological host-specific and geographical variation of the species in burbot and lenok from Lake Baikal was investigated by Baldanova and Pronin [2001]. Amin [2013] suggested moving Pseudoechinorhynchus borealis (Linstow 1901) to the genus Echinorhynchus under the name $E$. cinctulus.

Found in anadromous smelt from the Gulf of Bothnia [Valtonen et al., 2012] and in lacustrine smelt from Karelian waters (6\%, +, $7 \%$ ) [Rumyantsev et al., 2001; Rumyantsev, 2007]. In smelt the parasite is rare and scant.

\section{Echinorhynchus bothniensis Zdzitowiecki et Valtonen 1987}

In the Gulf of Bothnia the parasite is hosted by many fish species: lamprey, herring, pike, Altantic salmon, coregonids, burbot, sticklebacks, gobies, percids, European flounder. Differs from other members of this genus in that its intermediate hosts are not amphipods but mysids [Valtonen et al., 2012].

Records from smelt come from the Gulf of Bothnia and lakes of Finland [Valtonen et al., 2012].

\section{Echinorhynchus gadi Müller 1776}

Type species of its genus. Widespread in northern parts of the Atlantic and the Pacific Oceans. Has a wide range of definitive hosts and quite many amphipod crustacean intermediate hosts. Belongs to the marine ecological grouping of parasites. Preferred hosts are gadids. Found in migratory salmonids, pike and burbot from the Kola Peninsula [Mitenev, 1997].
Found in smelt from the Kola Peninsula [Mitenev and Schulman, 1999]. In smelt the parasite is rare and scant.

\section{Echinorhynchus salmonis Müller 1780}

Known under the name of Metechinorhynchus salmonis Müller 1784 as a type species of the genus Metechinorhynchus. Occurs in fresh and brackish waters of the Holarctic region. Common hosts are salmonoid fish, but can develop to maturity in a wide range of hosts. Intermediate hosts are amphipods Gammarus, Pallaseopsis, Monoporeia, Diporeia [Valtonen and Crompton, 1990].

Found in anadromous smelt from the Gulf of Finland (30-100\%), in lacustrine smelt from lakes of Karelia: Pertozero (13\%), Ladoga, Onego, Pyaozero (25\%, $5 \%, 100 \%$ ) [Petrushevsky and Bykhovskaya-Pavlovskaya, 1935; Barysheva and Bauer, 1957; Rumyantsev, 2007; Voigt, 1975].

\section{Pomphorhynchus laevis (Müller 1776)}

Widespread parasite of freshwater and marine fish. Intermediate hosts are various amphipod species. Studies with flounder showed that gammarids were a major factor for the prevalence and intensity of $P$. laevis infection in the fish. The parasite mainly infests juveniles. Gonads contained only encapsulated larvae. Kennedy et al. [1989] distinguished several biological strains of this acanthocephalan in Europe: Central European, English and Irish (all freshwater) and marine strains in the Baltic and the North Seas. Occurs in marine fish, including Baltic herring, in the Baltic Sea up to the Gulf of Finland [Hine and Kennedy, 1974]. Does not reach maturity in many fish species.

Found in anadromous smelt from the North Sea coast [Marre, 1931].

\section{Corynosoma semerme (Forssell 1904)}

Body cavity and internal organs. Widespread Palaearctic species. Representative of the marine faunal complex. Considered to be a relict in fresh water. The first intermediate host is the amphipod Pontoporeia affinis. Fish of various taxonomic groups can serve as paratenic hosts. Definitive hosts are marine mammals (in Lake Ladoga it is Ladoga seal), less often piscivorous birds.

Found in smelt from the Gulf of Riga and Lake Ladoga, the Gulf of Bothnia and lakes of Finland [Barysheva and Bauer, 1957; Rumyantsev, 2007; Valtonen et al., 2012].

\section{Corynosoma strumosum (Rudolphi 1802)}

Widespread Palaearctic species. Marine. Considered to be a relict in fresh water. Sexually mature forms are intestinal parasites of marine mammals and piscivorous birds. Arctic and North Pacific populations differ in the range of definitive hosts, size, age and sex structure [Popov and Fortunatto, 1987]. Intermediate hosts are amphipods of the genus Pontoporeia; various marine, migratory and 
freshwater fish serve as additional or second intermediate hosts. Body cavity and internal organs.

Found in anadromous and lacustrine smelt from the Gulf of Bothnia [Valtonen et al., 2012], Lake Ladoga (25\%) [Rumyantsev, 2007], the Northern Dvina [Schulman and Schulman-Albova, 1953].

Acanthocephalan parasites of smelt are a group of relatively few (7) species. None of the species are specialist parasites of smelt. Three species belong to the genus Echinorhynchus. If the suggestion by Amin [2013] to move P. borealis to the genus Echinorhynchus is supported, then 4 of the 7 acanthocephalan species known from smelt would belong to the genus Echinorhynchus. Acanthocephalans of this genus constitute a large and widespread group of parasites of bony fish and crustaceans, with the geographic distribution spanning from the Arctic to the Antarctic. Three members of this genus found in smelt live in fresh and brackish waters. They are widespread in fish of various families and orders.

Pseudoechinorhynchus borealis typically parasitizes burbot Lota lota (L.), but may occur in a wide range of other hosts: Atlantic salmon, brown/sea trout, arctic char, whitefish, grayling, pike, roach, ide, pike-perch, perch, ruffe, bullhead [Rumyantsev and leshko, 1997]. In Lake Baikal this acanthocephalan was found in burbot, lenok, Kessler's sculpin, stone sculpin, grayling, pike, perch, whitefish, cisco. A transfer of this parasite to Baikal seal was reported by Baldanova and Pronin [2001]. Most often occurs in Eastern Europe, and is rare in Western Europe.

The widest range of hosts is used by $E$. bothniensis. E. bothniensis Zdzitowiecki \& Valtonen, 1987 was described as a parasite of smelt from the Gulf of Bothnia. In earlier studies, the acanthocephalans from smelt were identified as $E$. gadi. The first evidence that $E$. gadi from $O$. eperlanus is biologically distinct from E. gadi from Gadus morhua and other marine fish was gathered through experimental infestation of amphipods: E. gadi acanthors isolated from cod successfully developed in Gammarus zaddachi, whereas acanthors from smelt did not. Afterwards, morphological distinctions between acanthocephalans from cod and smelt were detected, viz. overall body size of females (they were smaller in smelt), size of eggs, number and position of cement glands. Valtonen et al. [2012] recorded $E$. bothniensis from a wide range of hosts (14 fish species) from the Gulf of Bothnia. Apart from smelt, gravid females were found in Lampetra fluviatilis (L.), Salmo trutta L., Lota lota (L.), Myoxocephalus quadricornis (L.), and Platichthys flesus (L.) [Valtonen and Crompton, 1990]. The intermediate host for $E$. bothniensis is Mysis relicta [Wayland, 2013]. Allozyme analysis showed that
E. bothniensis is a complex species: acanthocephalans from smelt from the Gulf of Bothnia, smelt and $M$. relicta from Lake Keitele (Central Finland) differ from $E$. bothniensis derived from Coregonus lavaretus (L.), Platichthys flesus (L.), S. alpinus (L.) and Mysis segerstralei [Audzijonyte \& Väinölä, 2005]. Distinctions were also found between acanthocephalans from smelt from the Gulf of Bothnia and from Lake Pulmankijärvi (Northern Finland). E. bothniensis populations from the Gulf of Bothnia and Lake Keitele have presumably remained in reproductive isolation for at least 6000 years. As evidenced by allozyme electrophoresis, E. bothniensis genetically speciated but did not diverge in regular morphological characters. The absence of adaptive morphological modifications is probably the result of parasitism on similar definitive and intermediate hosts (smelt and mysids), as well as a relatively short time period for allopatric speciation [Väinölä et al., 1994].

E. salmonis is a common parasite of salmonoid and other fish inhabiting fresh and brackish waters of the Holarctic region. In Lake Baikal there occur two forms: E. s. salmonis (main hosts are whitefish, grayling) and E. s. baicalensis (main hosts are endemic cottids). E. s. salmonis from two host species, grayling and cisco, had host-specific differences [Baldanova and Pronin, 2001]. Studies of the morphology of Echinorhynchus salmonis from whitefish and smelt from the Gulf of Bothnia have demonstrated that Palaearctic populations of this acanthocephalan have a wide range of morphological variation and do not differ from Nearctic populations [Wayland et al., 2005]. Echinorhynchus gadi mainly parasitizes Gadidae. Allozyme analysis showed that Echinorhynchus gadi from North Atlantic gadids falls into at least 3 closely related species. The first species (I) occurs in the Northern Baltic, Norwegian and North Seas. The second one (II) was found only in the North Sea and the third one (III) only in the Norwegian Sea [Shostak et al., 1986]. Morphological and genetic variation (18S rRNA) in Echinorhynchus gadi from Atlantic cod from different fishing grounds in the Baltic Sea and North Atlantic was studied by Sobecka et al. [2011]. Nucleotide sequences of Echinorhynchus gadi rDNA from cod caught at all sampling sites proved to be identical. Morphologically, the acanthocephalans fell into 2 groups corresponding approximately to the systematic classification of cod into the 2 subspecies, Atlantic and Baltic. Analysis of the 18S rRNA sequence marker in Echinorhynchus gadi did not reveal genetic differentiation between North Atlantic and Arctic populations of Atlantic cod Gadus morhua L. [Wayland et al., 2015].

Two species (Corynosoma semerme and C. strumosum) belong to the species-richest (ca. 
30 species) genus in the family Polymorphidae. The genus Corynosoma is widespread in marine mammals and shorebirds. It is currently held that this genus falls into 2 morphologically and ecologically distinct groups: the 'marine' group (with 30 species), which parasitizes mammals and piscivorous birds associated with marine waters, and the 'freshwater' group (with 7 species) - parasites of shorebirds associated with continental waters [García-Varela et al., 2005].

The genus Pomphorhynchus in the Palaearctic region is associated with cyprinids. Pomphorhynchus laevis is one of the species in this genus, and is known as a parasite using a wide range of cyprinids, mainly as reservoir hosts. Pomphorhynchus laevis may, however, parasitize also fish of other taxonomic groups. In Lake Sevan, for instance, it was found in Sevan whitefish and Sevan trout [Voropaeva, Tolstenkov, 2008]. After the study of the distribution, specificity and pathogenicity of Pomphorhynchus laevis from the Avon River, Hampshire, only chub Leuciscus cephalus (L.) and barbel Barbus barbus (L.) were recognized as its preferred hosts [Hine and Kennedy, 1974].

Many fish species act as paratenic hosts for acanthocephalans. Acanthocephalan larvae can be found in accidental hosts - fish or birds. Smelt is an intermediate and paratenic host for species of genera Corynosoma and Pomphorhynchus. For the remaining 4 acanthocephalan species smelt is a definitive host. Four species have freshwater distribution and a wide range of hosts. E. botniensis and Pomphorhynchus laevis have been found in the greatest number of hosts. In northern freshwater lakes, Pomphorhynchus laevis was found only in ide (Lake Onego) [Rumyantsev and leshko, 1997]. Echinorhynchus salmonis is more frequently hosted by salmonids and Pseudoechinorhynchus borealis by burbot. A majority of acanthocephalan species retrieved from smelt are typical inhabitants of northern water bodies.

All the studied ananthocephalan species ( $P$. borealis from burbot and lenok, $M$. salmonis from whitefish and smelt, E. gadi from cod, E. bothniensis from smelt) demonstrate high individual variability. The greatest range of variation is observed in morphometric characters: dimensions of the body and internal structures, whereas meristic characters are the most constant [Gichenok, 1995; Baldanova and Pronin, 2001; Wayland et al., 2005, 2015]. Acanthocephalans exhibit more specificity towards their intermediate than definitive hosts [Baldanova and Pronin, 2001]. Acanthocephalans feature post-cyclic transmission.

Fish leeches and glochidia are encountered in mainland waters of northern continents. They parasitize many species of fish of various orders and families. Smelt host one species of each, with low abundances.

\section{Class Hirudinea Lamarck 1809}

\section{Piscicola geometra (Linnaeus 1761)}

Skin. Probably Holarctic species. Representative of the Boreal flatland faunal complex. Found in many fish species. Among salmonoid fish of Fennoscandia the parasite is known from Atlantic salmon, brown trout, Arctic char, vendace, whitefish and grayling.

Reported from anadromous smelt from the German coast of the North Sea [Marre, 1931; Anders and Möller, 1991].

\section{Class Bivalvia Linnaeus 1785}

\section{Anadonta anatina Linnaeus 1758}

Skin, gills. Widespread in northern Germany. More likely to occur in uncontaminated areas of large lakes.

Found in anadromous smelt from the Eider River [Anders and Möller, 1991; Anders and Wiese, 1993]. Rumyantsev [2007] mentioned a glochidium of undertermined species of the family Unionidae from freshwater smelt from Lake Onego.

\section{Class Crustacea Lamarck 1801}

\section{Ergasilus briani Markewitsch 1932}

Gill parasite of many fish species, mainly cyprinids. Palaearctic distribution. Representative of the Boreal flatland faunal complex. Thermophilic and limnophilic. Widespread.

Found in dwarf smelt from Lake Beloye $(0.1 \%)$. This parasite was found on gills of 13 fish species from this lake [Radchenko, 1999].

\section{Ergasilus sieboldi Nordmann 1832}

Widespread Palaearctic species. Representative of the Boreal flatland faunal complex. Thermophilic and limnophilic. Pathogenic in a wide range of hosts.

Occurs in anadromous (Denmark, German coast, Poland [Palm et al., 1999]) and freshwater smelt: Lakes Chudskoye, Pskovskoye, IImen, Ladoga ( $48.3 \%, 50 \%, 10-15 \%, 7 \%$ etc.) [Khlopina, 1920; Barysheva and Bauer, 1957]. Found in dwarf smelt from Lake Beloye $(2.5 \%$, mean intensity 9.0, abundance index 0.22) [Radchenko, 1999]. Izyumova [1974] reported this species from dwarf smelt sampled in May 1972 with 40 \% prevalence and 1-4 intensity.

\section{Lepeophtheirus sp.}

Belongs to the marine ecological grouping of parasites. Around 90 species have been retrieved from a variety of marine fishes. One species of this genus occurs on salmonid fish migrating from the sea to river estuaries for spawning. Pathogenic in salmon farms.

Found in anadromous smelt from the German coast of the North Sea [Marre, 1931]. 


\section{Caligus elongatus Nordman 1832}

Belongs to the marine ecological grouping of parasites. Preferred hosts are European plaice, mullet, sea trout. A very important pathogen of sea-farmed Atlantic salmon. The life cycle consists of 8 stages: 2 nauplii, 1 copepodid, 4 chalimi, and adult. The generation time is $\mathbf{4 3}$ days. Two generations can develop a year. Males die after copulation. Females overwinter [Piasecki and MacKinnon, 1995]. Two mitochondrial genotypes have been described for Caligus elongatus Nordman in Norway [Øines and Heuch, 2007].

Found in anadromous smelt from the German coast of the North Sea [Marre, 1931].

Caligus lacustris Steenstrup \& Lütken 1861

Body surface. Representative of the Boreal flatland faunal complex (Ponto-Caspian group). Palaearctic species. The only freshwater species in this marine genus. Hosted by various freshwater fish species: brown trout, Arctic char, vendace, smelt, white bream, common bream, pike, perch in Europe.

Found in lacustrine smelt from lakes Ladoga (44 \%, M 0.9) and Onego (10 \%; M 0.2) [Rumyantsev, 2007], as well as in anadromous smelt from the Gulf of Bothnia [Valtonen et al., 2012].

\section{Argulus foliaceus (Linnaeus 1758)}

One of the most widespread freshwater parasites in the European North. Hosted by various freshwater fish species (whitefish, pike, minnow, ide, nine-spined stickleback, perch, ruffe). Coasts of the North Sea and Baltic Sea. Palaearctic. Representative of the Boreal flatland faunal complex. Occurs also on other continents. Thermophilic. Pathogenic.

Found in lacustrine smelt from Lake Ladoga (7 \%) [Barysheva and Bauer, 1957], Lake Ukshezero (6.6 \%) [Petrushevsky and Bykhovskaya-Pavlovskaya, 1935], the Pechora River [Ekimova, 1962]. Found in smelt from Lake Vygozero (13.3\%; M 1). Smelt migrated down the Segezha River from Lake Segozero, into which it had been stocked as eggs from Lake Ladoga, and became a common species in both lakes [Rybak, 1982]. Izyumova [1974] found this crustacean in Lake Beloye in $10 \%$ of its dwarf smelt (intensity 1-2 specimens) in May 1972.

\section{Lernaeocera branchialis (Linnaeus 1758)}

Marine. Widespread Holarctic species. Pathogenic parasite of gadids and pleuronectids in brackish sea areas and river estiaries.

Found in anadromous smelt on the coast of the North Sea (Wadden Sea) [Möller and Anders, 1991].

Crustacean parasites of smelt form an ecologically diverse group comprising marine and freshwater species predominantly of marine origin. Four species live in fresh water: E. briani, ErgasiIus sieboldi, Argulus foliaceus, Caligus lacustris.
The latter is widespread in West European waters. E. briani has been reported only from dwarf smelt. Argulus foliaceus (one of the most widespread parasites in lakes) is a rare encounter in smelt. Caligus elongates parasitizes marine fish. Three species are pathogenic.

We are grateful to S. G. Sokolov (IPEE RAS), who gave very good comments on an earlier version of this paper. The studies were carried out with funding from the federal budget allocated under state order (state reg. ID 0221-2014-0030) and within the "Biological Resources of Russia" program.

\section{References}

Anikieva L. V. Ispol'zovanie gel'mintologicheskikh dannykh pri otsenke sostoyaniya vodoema [Use of helminthological data for assessing water body conditions]. Ekologiya paraziticheskikh organizmov v biogeotsenozakh Severa [Ecology of parasites in biogeocenoses of the North]. Petrozavodsk: KF AN SSSR, 1982. P. 72-83.

Anikieva L. V. Tsestody roda Proteocephalus iz koryushki Osmerus eperlanus [Cestodes Proteocephalus from the smelt Osmerus eperlanus]. Parazitologiya [Parasitology]. 1998. Vol. 32, iss. 2. P. 134-140.

Anikieva L. V., Dorovskikh G. N. Polimorfizm i vnutrividovaya izmenchivost' spetsifichnogo parazita koryushek - cestody Proteocephalus tetrastomus (Rudolphi, 1810) (Cestoda, Proteocephalidea) [Polymorphism and intraspecific variability in the cestode Proteocephalus tetrastomus (Rudolphi, 1810) (Cestoda, Proteocephalidea), a specific parasite of the smelt]. Parazitologiya [Parasitology]. 2009. Vol. 43, iss. 4. P. 309-316.

Anikieva L. V., leshko E. P. Mikroevolyutsionnye aspekty morfologicheskoi izmenchivosti i specifichnosti cestod na primere parazita sigovykh ryb tsestody Proteocephalus longicollis (Zeder, 1800) (Proteocephalidae) [Microevolutionary aspects of morphological variability and specificity of cestodes by the example of Proteocephalus longicollis (Zeder, 1800) (Proteocephalidea), a parasite of the Coregonidae]. Parazitologiya [Parasitology]. 2010. Vol. 44, iss. 3. P. 217-225.

Anikieva L. V., leshko E. P., II'mast N. V. Raspredelenie chislennosti i struktura populyatsii ProteocephaIus longicollis (Zeder, 1800) (Cestoda: Proteocephalidea) - parazita koryushki i sigovykh ryb [Distribution of the abundance and structure of the population Proteocephalus longicollis (Zeder, 1800) (Cestoda: Proteocephalidea), a parasite of the smelt and Coregonidae]. Parazitologiya [Parasitology]. 2016a. Vol. 50, iss. 4. P. 291-302.

Anikieva L. V., leshko E. P., Rumyantsev E. A. Ekologicheskii analiz gel'mintov ryapushki i koryushki Onezhskogo ozera [Ecological analysis of helminths in the vendace and smelt from Lake Onego]. Trudy Karel'skogo nauchnogo tsentra RAN [Trans. of KarRC of the RAS]. 2016b. No. 4. P. 37-47.

Anikieva L. V., Malakhova R. P., leshko E. P. Ekologicheskii analiz parazitov sigovykh ryb [Ecological 
analysis of parasites of the Coregonidae]. Leningrad: Nauka, 1983. 168 p.

Anikieva L. V., Rumyantsev E. A. Tsestody ryb ozer Karelii [Fish cestodes in lakes of Karelia]. Problemy tsestodologii [Problems of Cestology]. 2005. Iss. III. P. 40-62.

Atlas presnovodnykh ryb Rossii [Atlas of freshwater fish of Russia]. Ed. Yu. S. Reshetnikov. Vol. 1. Second edition. Moscow: Nauka, 2003. 379 p.

Baldanova D. R., Pronin N. M. Skrebni (tip Acanthocephala) Baikala: Morfologiya i ekologiya [Thornyheaded worms (phylum Acanthocephala) of Lake Baikal: morphology and ecology]. Novosibirsk: Nauka, 2001. $158 \mathrm{p}$.

Barskaya Yu. U., leshko E. P., Lebedeva D. I. Parazity lososevidnykh ryb Fennoskandii [Parasites of salmonoids in Fennoscandia]. Petrozavodsk: KarRC of RAS, 2008. $168 \mathrm{p}$.

Barysheva A. F., Bauer O. N. Parazity ryb Ladozhskogo ozera [Parasites of fish in Lake Ladoga]. Izv. VNIORH [Bull. of the All-Union Sci. Inst. of Lake and River Fishery]. 1957. Vol. 42. P. 175-226.

Berg L. S. Ryby presnykh vod SSSR i sopredel'nykh stran [Fish of freshwater bodies of the USSR and adjacent countries]. Moscow; Leningrad: Izd-vo AN SSSR, 1948. Pt. 1. 466 p.

Boguckaya N. G., Naseka A. M. Katalog beschelyustnykh i ryb presnykh i solonovatykh vod Rossi s nomenklaturnymi i taksonomicheskimi kommentariyami [A catalogue of jawless animals and fish of freshwater and saltish waters of Russia with classification and taxonomic commentary]. Moscow: Tov-vo nauchn. izd. KMK, 2004. 389 p.

Delyamure S. L., Skryabin A. S., Serdyukov A. M. Osnovy tsestodologii. Difillobotriidy - lentochnye gel'minty cheloveka, mlekopitayushchikh i ptits [Fundamentals of cestology. Tapeworms of the Diphyllobothrium genus in humans, mammals, and birds]. Vol. XI. Moscow: Nauka, 1985. 199 p.

Dorovskikh G. N. Parazity presnovodnykh ryb severo-vostoka Evropeiskoi chasti Rossii (fauna, ekologiya parazitarnykh soobshchestv, zoogeografiya) [Parasites of freshwater fish in the northeast of the European part of Russia (fauna, parasite community ecology, zoogeography)]: DSc (Dr. of Biol.) thesis. St. Petersburg: ZIN RAN, 2002. $760 \mathrm{p}$.

Ekimova I. V. Materialy po parazitofaune ryb r. Pechory [Materials on the fish parasitofauna of the Pechora river]. Voprosy ikhtiologii [Journal of Ichthyology]. 1962. Vol. 2, iss. 3/24. P. 542-546.

Freze V. I. Proteotsefalyaty - lentochnye gel'minty ryb, amfibii i reptilii [Cestodes Proteocephalata in fish, amphibians, and reptiles]. Moscow; Leningrad: Nauka, 1965. 538 p.

Gichenok L. A. Izmenchivost' i fenotipicheskoe raznoobrazie skrebnya Echinorhynchus gadi (Acanthocephala) iz dvukh vidov belomorskikh ryb [Variability and phenotypic diversity of the thorny-headed worms Echinorhynchus gadi (Acanthocephala) from two species of the White Sea fish]. Zool. zhurn. [Russ. Journal of Zoology]. 1995. Vol. 74, iss. 8. P. 15-26.

Ivanova M. N. Populyatsionnaya izmenchivost' presnovodnykh koryushek [Population variability of the freshwater smelt]. Ed. A. V. Monakov. Rybinsk.: Izd-vo Instituta biologii vnutrennikh vod, 1982. $143 \mathrm{p}$.

leshko E. P., Evseeva N. V., Sterligova O. P. Rol' parazitov ryb v presnovodnykh ekosistemakh na primere parazita koryushki (Osmerus eperlanus) [Role of fish parasites in freshwater ecosystems: case of a parasite of the smelt Osmerus eperlanus]. Parazitologiya [Parasitology]. 2000. Vol. 34, iss. 2. P. 118-123.

Izyumova N. A. Parazitofauna snetka Belogo ozera, Rybinskogo i Uglichskogo vodokhranilishch [Parasitofauna of the European smelt in Lake Beloe, Rybinsk and Uglich reservoirs]. Flora, fauna i mikroorganizmy Volgi [Flora, fauna, and microorganisms of the Volga river]. Rybinsk: IBVV AN SSSR, 1974. P. 286-289.

Karasev A. B., Ponomarev S. V., Eremenko O. S. Parazitofauna evropeiskoi koryushki Osmerus eperlanus nekotorykh izolirovannykh ozernykh populyatsii SeveroEvropeiskoi chasti Rossii [Parasitofauna of the European smelt Osmerus eperlanus of some isolated lake populations in the European North of Russia]. Biologicheskie resursy Belogo morya i vnutrennikh vodoemov Evropeiskogo Severa. Mater. XXVIII mezhdunarodnoi konferentsii 5-8 oktyabrya $2009 \mathrm{~g}$. [Biological Res. of the White Sea and Inland Water Bodies of the European North: Proceed. of the XXVIII Int. Conf. (October 5-8, 2009)] Petrozavodsk, 2009. P. 266-269.

Khlopina N. P. K voprosu o paraziticheskikh zabolevaniyakh snetkov [On parasitic diseases of the European smelt]. Izv. otd. rybovodstva [Proceed. of the Pisciculture Dep.]. 1920. Vol. 2. P. 92-95.

Klyukanov V. A. Proiskhozhdenie, rasselenie i evolyutsiya koryushkovykh (Osmeridae). Sb. nauch. tr. [The origine, distribution, and evolution of the smelt (Osmeridae): collection of scientific papers]: Osnovy klassifikatsii i filogenii lososevidnykh ryb [Basics of classification and phylogeny of the salmonoids]. Leningrad: ZIN AN SSSR, 1977. P. 13-27.

Kogteva E. P. Parazity ryb Pskovsko-Chudskogo vodoema [Parasites of fish in Lake Pskov-Chudskoye]. Izvestiya VNIORH [Bull. of the All-Union Sci. Inst. of Lake and River Fishery]. Leningrad, 1957. Vol. XLII. P. 243-269.

Kriksunov E. A., Bobyrev A. E., Burmenskii V. A., Pavlov V. N., Il'mast N. V., Sterligova O. P. Balansovaya model' bioticheskogo soobshchestva Syamozera [Balance model of the biotic community of Lake Syamozero]. Petrozavodsk: KarRC of RAS, 2005. 54 p.

Kudryavtseva E. S. Parazitofauna ryb r. Sukhony i Kubenskogo ozera [Parasitofauna of the Sukhona river and Lake Kubenskoye]. Zool. zhurn. [Russ. Journal of Zoology]. 1957. Vol. 36, iss. 9. P. 1292-1304.

Kuperman B. I. Lentochnye chervi roda Triaenophorus - parazity ryb [Tapeworms Triaenophorus as fish parasites]. Leningrad: Nauka, 1973. 208 p.

Kuperman B. I. Ekologicheskii analiz tsestod ryb vodoemov Volgo-Baltiiskoi sistemy (Rybinskoe, Sheksninskoe vodokhranilishcha, Beloe, Onezhskoe, Ladozhskoe ozera) [Ecological analysis of fish cestodes of the VolgaBaltic system (Rybinsk and Sheksna reservoirs, Lakes Beloe, Onego, Ladoga)]. Fiziologiya i parazitologiya presnovodnykh zhivotnykh [Physiology and Parasitology of Freshwater Animals]. Leningrad: Nauka, 1979. P. 133-159. 
Lutta A. S. O zarazhenii aral'skogo shipa (Acipenser nudiventris) zhabernym sosal'shchikom Nitzschia sturionis [On the contamination of the Aral thorn sturgeon with Nitzschia sturionis]. Tr. Leningr. obshch. estestvoisp. [Proceed. of the Leningrad Society of Naturalists]. 1941. Vol. 18, iss. 4. P. 40-60.

Mitenev V. K. Parazity presnovodnykh ryb Kol'skogo Severa [Parasites of freshwater fish in the Kola North]. Murmansk: PINRO, 1997.199 p.

Mitinev V. K., Shul'man B. S. Parazity ryb Murmanskoi oblasti. Sistematicheskii katalog [Fish parasites of Murmansk Oblast. A classified catalogue]. Murmansk: PINRO, 1999. $72 \mathrm{p}$.

Nel'son D. S. Ryby mirovoi fauny [Fish of world fauna]. The $4^{\text {th }}$ rev. Eng. ed. tr. by N. G. Bogutskaya. Eds. A. M. Naseka, A. S. Gerd. Moscow: Knizhnyi dom Librokom, 2009. 880 p.

Opredelitel' parazitov presnovodnykh ryb fauny SSSR [An identification guide of freshwater fish parasites of the fauna of the USSR]. Vol. 1: Paraziticheskie prosteishie [Vol. 1: Protozoan parasites]. Leningrad: Nauka, 1984. 431 p.; Vol. 2: Paraziticheskie mnogokletochnye (1-ya chast') [Vol. 2: Parasitic multicellular (part 1)] Leningrad: Nauka, 1985. 425 p.; Vol. 3: Paraziticheskie mnogokletochnye (2-ya chast') [Vol. 3: Parasitic multicellular (part 2)]. Leningrad: Nauka, 1987. 583 p.

Petrushevskii Yu. K., Byhovskaya I. E. O rasprostranenii lichinok shirokogo lentetsa v rybah Karelii [On the distribution of broad tapeworm larvae in fish of Karelia]. Tr. Borodinskoi biolog. stantsii [Proceed. of the Borodinskaya biological st.]. Leningrad, 1933. Vol. 6, iss. 2. P. 5-26.

Petrushevskii Yu. K., Byhovskaya-Pavlovskaya I. E. Materialy po parazitologii ryb Karelii. 1. Parazity ryb raiona Konchezera [Materials on parasitology of fish in Karelia. 1. Fish parasites in the vicinity of the settlement of Konchezero]. Tr. Borodinskoi biolog. stantsii [Proceed. of the Borodinskaya biological st.]. Leningrad, 1935. Vol. 8, iss. 1. P. 15-77.

Popov V. N., Fortunato M. E. Geograficheskaya izmenchivost' Corynosoma strumosum (Acanthocephala, Polymorphidae), parazita morskikh mlekopitayushchikh [Geographical variability of Corynosoma strumosum (Acanthocephala, Polymorphidae), a parasite of marine mammals]. Zool. zhurnal [Russ. Journal of Zoology]. 1987. Vol. 66, iss. 1. P. 12-18.

Pugachev O. N. Katalog parazitov presnovodnykh ryb Severnoi Azii. Prosteishie [A catalogue of freshwater fish parasites in Northern Asia. Protozoa]. St. Petersburg: ZIN RAN, 2001. 242 p.

Pugachev O. N. Katalog parazitov presnovodnykh vodoemov Severnoi Azii. Knidarii, monogenei, cestody [A catalogue of parasites of freswater bodies in Northern Asia. Cnidarians, Monogenea, cestodes]. Tr. ZIN RAN [Proceed. of the Zoological Inst. of the RAS]. St. Petersburg, 2002. Vol. 297. 248 p.

Pugachev O. N. Katalog parazitov presnovodnykh vodoemov Severnoi Azii. Trematody [A catalogue of parasites of freswater bodies in Northern Asia. Trematodes]. Tr. ZIN RAN [Proceed. of the Zoological Inst. of the RAS]. St. Petersburg, 2003. Vol. 298. 224 p.

Pugachev O. N. Katalog parazitov presnovodnykh ryb Severnoi Azii. Nematody, skrebni, piyavki, rakoobraznye, kleshchi [A catalogue of freshwater fish parasites in Northern Asia. Nematodes, thorny-headed worms, leeches, crustaceans, ticks]. Tr. ZIN RAN [Proceed. of the Zoological Inst. of the RAS]. St. Petersburg, 2004. Vol. 304. 250 p.

Radchenko N. M. Parazity ryb Belogo ozera [Fish parasites in Lake Beloye]. Vologda: Vologodskii institut razvitiya obrazovaniya, 1999. $170 \mathrm{p}$.

Radchenko N. M. Parazity ryb ozera Vozhe [Fish parasites in Lake Vozhe]. Vologda: Vologodskii institut razvitiya obrazovaniya, 2002. $200 \mathrm{p}$.

Reshetnikov Yu. S., Popova O. A., Sterligova O. P. Izmenenie struktury rybnogo naseleniya evtrofiruemogo vodoema [Changes in ichthyofauna of an eutrophicated water body]. Moscow: Nauka, 1982. 234 p.

Rumyancev E. A. Parazity ryb $v$ ozerakh Evropeiskogo Severa [Fish parasites in lakes of the European North]. Petrozavodsk: PetrGU, 2007. 252 p.

Rumyantsev E. A., leshko E. P. Parazity ryb vodoemov Karelii. Sistematicheskii katalog [Fish parasites in water bodies of Karelia. A classified catalogue]. Petrozavodsk: KarRC of RAS, 1997. 120 p.

Rumyancev E. A., Permyakov E. V. Parazity ryb Pyaozera [Fish parasites in Lake Pyaozero]. Ekologicheskaya parazitologiya [Ecological Parasitology]. Petrozavodsk: KarRC of RAS, 1994. P. 53-78.

Rumyantsev E. A., Shul'man B. S., leshko E. P. Gyrodactylus osmeri (Monogenea) - parazit koryushki (Osmerus eperlanus) [Gyrodactylus osmeri (Monogenea) a parasite of the smelt (Osmerus eperlanus)]. Parasitologiya [Parasitology]. 1998. Vol. 32, iss. 1. P. 95-96.

Rumyantsev E. A., Shul'man B. S., leshko E. P. Parazitofauna ryb Ladozhskogo ozera [Fish parasitofauna of Lake Ladoga]. Ekologo-parazitologicheskie issledovaniya zhivotnykh i rastenii Evropeiskogo severa [Ecological and Parasitological Res. of Animal and Plants in the European North]. Petrozavodsk: KarRC of RAS, 2001. P. 25-29.

Rybak V. F. Formirovanie parazitofauny ryb Vygozerskogo vodokhranilishcha [Formation of fish parasitofauna in Vygozero reservoir]. Ekologiya paraziticheskikh organizmov v biogeotsenozakh Severa [Ecology of Parasites in Biogeocenoses of the North]. Petrozavodsk: Karel. fil. AN SSSR, 1982. P. 59-72.

Sterligova O. P., Keto Y. U., Kaukaranta M. Biologiya koryushki Osmerus eperlanus ozera Vesiyarvi (Finlyandiya) [Biology of the smelt Osmerus eperlanus in Lake Vesijärvi (Finland)]. Vopr. ikhtiol. [Journal of Ichthyology]. 1992. Vol. 32, iss. 3. P. 166-168.

Sterligova O. P., Il'mast N. V. Sostoyanie populyatsii koryushki Osmerus eperlanus Vygozera i Syamozera, sformirovavshikhsya $v$ rezul'tate samorasseleniya [The state of the smelt Osmerus eperlanus populations formed as a result of self distribution in Lakes Vygozero and Syamozero]. Vopr. Ihtiol. [Journal of Ichthyology]. 2012. Vol. 52, iss. 3. P. 358-364.

Sterligova O. P., II'mast N. V., Savosin D. S. Kruglorotye i ryby presnykh vod Karelii [Cyclostomes and fish of freshwater bodies in Karelia]. Petrozavodsk: KarRC of RAS, 2016. 224 p.

Sterligova O. P., Pavlov V. N., Il'mast N. V., Pavlovskii S. A., Komulainen S. F., Kuchko Ya. A. Ekosistema Syamozera (biologicheskii rezhim, ispol'zovanie) 
[The ecosystem of Lake Syamozero (biological regime, usage)]. Petrozavodsk: KarRC of RAS, 2002. 119 p.

Shul'man S. S., Shul'man-Al'bova R. E. Parazity ryb Belogo morya [Fish parasites in the White Sea]. Moscow; Leningrad: AN SSSR, 1953. 198 p.

Voronin V. N. Pleistophora ladogensis sp. n. - mikrosporidiya (Protozoa, Mikrosporidia) iz muskulatury nalima Lota lota i koryushki Osmerus eperlanus eperlanus ladogensis [Pleistophora ladogensis sp. n. (Protozoa, Microsporidia) from muscles of Lota lota and Osmerus eperlanus eperlanus ladogensis]. Parazitologiya [Parasitology]. 1978. Vol. 12, iss. 5. P. 453-455.

Voropaeva E. L., Tolstenkov O. O. K izucheniyu parazitofauny ryb oz. Sevan [On the study of fish parasitofauna of Lake Sevan]. Mater. IV Vseros. s'ezda parazitol. o-va RAN [Proceed. of the IV All-Russ. Congress of Parasit. Society of the RAS]. St. Petersburg, 2008. Vol. 1. P. $138-141$

McAllister D. E. A revision of the smelt family Osmeridae, Bull. Nat. Mus. Can., 1963. No. 191. 53 p.

Amin O. M. Classification. In: D. W. T. Crompton and B. B. Nickol (Eds.). Biology of the Acanthocephala. Cambridge University Press, London and New York, 1985. P. 27-72.

Amin O. M. Classification of the Acanthocephala. Folia Parasitologica. 2013. Vol. 60, no. 4. P. 273-305.

Anders K., Möller H. Atlas der Fischkrankheiten im Wattenmeer. Umweltbundesamt Berlin (Scientific Report 10204373/1, UBA-FB 91-048). 1991. 112 p.

Anders K., Wiese V. Glochidia of the freshwater mussel, Anadonta anatine, affecting the anadromous European smelt (Osmerus eperlanus) from the Eider estuary< Gemany. Journal of Fish Biology. 1993. Vol. 42. P. 411-419.

Audzijonytė A., Väinölä R. Diversity and distributions of circumpolar fresh- and brackish-water Mysis (Crustacea: Mysida): descriptions of M. relicta Lovén, 1862, M. salemaai n. sp., M. segerstralei n. sp. and M. diluviana n. sp., based on molecular and morphological characters. Hydrobiologia. 2005. Vol. 544. P. 89-141.

Bylund $G$. Delimination and characterization of European Diphyllobothrium species. Abo: Akad. Finland, 1975. $116 \mathrm{p}$.

Gibson D. I., Jones A., Bray A. R. (eds.). Keys to Trematoda. London, 2002. Vol. 1. 228 p.

Gibson D. I., Bray R. A., \& Harris E. A. (Compilers)). Host-Parasite Database of the Natural History Museum, London. 2005. URL: http://www.nhm.ac.uk/researchcuration/scientific-resources/taxonomy-systematics/ host-parasites/ (accessed: 27.10.2016).

Granath W. O., Gilbert M. A., Wyatt-Pescador E. J. and Vincent E. R. Epizootiology of Myxobolus cerebralis, the causative agent of salmonid whirling disease in the Rock Creek drainage of West-Central Montana. J. Parasitol. 2007. Vol. 93. P. 104-119.

García-Varela M., Nadler S. A. Phylogenetic relationships of Palaeacanthocephala (Acanthocephala) inferred from SSU and LSU rDNA gene sequences. Journal of Parasitology. 2005. Vol. 91, no. 6. P. 1401-1409. doi: 10.1645/GE-523

Hine P., Kennedy $C$. The population biology of the acanthocephalan Pomphorhynchus laevis (Müller) in the River Avon. J. Fish Biol. 1974. Vol. 6. P. 665-679.
Hanzelova V., Kuchta R., Scholz T., Shinn A. P. Morphometric analisis of four species of Eubothrium (Cestoda: Pseudophyllidea) parasites of salmonid fish: An interspecific and intraspecific comparison. Parasitology International. 2005. No. 54. P. 207-214.

Hartmann F. Untersuchungen zur Biologie, Epidemiologie und Schadwirkung von Anguillicola crassus Kuwahara, Niimi und Itagaki, 1974 (Nematoda), einem blutsaugendem Parasiten in der Schwimmblase des europäischen Aals (Anguilla anguilla). PhD. thesis, University Hamburg, Berichte aus der Biologie, Verlag Shaker (Aachen). 1994. 139 p.

Hoffman G. Parasite of North American Freshwater Fishes. Comstock Publishing Associates, Ithaca. 1999. $539 \mathrm{p}$.

Jarling C. Beitrag zur Kenntnis der Helminthenfauna des Stintes (Osmerus eperlanus) in der Unterelbe. MSc. thesis, University Hamburg. 1981. 95 p.

Jarling $C$. On the helminth fauna of the smelt (Osmerus eperlanus) in the Elbe estuary. Archiv für Hydrobiologie, Suplement 61 (3). 1982. P. 377-395.

Jones A., Bray A. R., Gibson D. I. (eds.). Keys to Trematoda. London, 2005. Vol. 2. 745 p.

Kahl W. Über den Befall des Stintes mit Larven des Fadenwurmes Porrocaecum decipiens. Der Fischmarkt. 1936. 7. P. 177-181.

Khalil L. F., Jones A., Bray R. A. (eds.). Keys to Cestode Parasites of Vertebrates. CAB International, Wallingford, United Kingdom, 1994. 751 p.

Kerstan S. L. Der Befall von Fischen aus dem Wattenmeer und dem Nordatlantik 1988-1990 mit Nematodenlarven und eine Bibliographie über parasitische Nematoden in Fischen und Seesäugern. PhD. thesis, Berichte aus dem Institut für Meereskunde an der Christian-Albrechts-Universität Kiel 219. 1992. 205 p.

Kennedy C. R., Bates R. M., Brown A. F. Discontinuous distributions of the fish acanthocephalans Pomphorhynchus laevis and Acanthocephalus anguillae in Britain and Ireland: an hypothesis. Journal of Fish Biology. 1989. Vol. 34. P. 607-619.

Kesting V. Untersuchungen zur Parasitenfauna von Kleinfischen und Schnecken der Ostseeförde Schlei. M. Sc. thesis, University Hamburg. 1992. 166 p.

Kirjušina M., Vismanis K. Checklist of the parasites of fishes of Latvia. FAO Fisheries technical paper. 2007. 369/3. $106 \mathrm{p}$.

Kuhn T., Benninghoff K., Horst H., Landry T., Klimpel S. Sealworm Pseudoterranova decipiens s. s. infection of European smelt Osmerus eperlanus in German coastal waters: ecological implications. DISEASES OF AQUATIC ORGANISMS. Dis Aquat Org. Vol. 2013. 102. P. 217-224. doi: 10.3354/dao02555

Lynn D. H., Small E. B. Phylum Ciliophora. An Illustrated Guide to the Protozoa. Eds. J. J. Lee, P. C. Bradbury, G. F. Leedale. Society of Protozoologists, Lawrence, Kansas, 2002. P. 371-656.

Malmberg G. Salmonid transports, culturing and Gyrodactylus infections in Scandinavia. Parasites of Freshwater Fishes of North-West Europe. Petrozavodsk. 1989. P. 88-104.

Marcogliese D. J. First Report of the Asian Fish Tapeworm in the Great lakes. J. Great Lakes Res. 34. 2008. P. 566-569. 
Marre G. Fischereiwissenschaftliche Untersuchungen über die Grundlagen der Stintfischerei im Kurischen Haff. Zeitschr. Fisch. XXXIX. 1931. 443. 512 p.

Molnar K., Szekely Cs. and Perenyi M. Dynamics of Anguillicola crassus (Nematoda: Dracunculoida) infection in eels of Lake Balaton, Hungary. Folia Parasitol. 1994. Vol. 41. P. 193-202.

Möller H. and Klatt S. The role of smelt as transmitter of sealworm Pseudoterranova decipiens in the Elbe estuary. International Council for the Exploration of the Sea C. M. 1988/E:13 Marine Environmental Quality Committee Ref. $\mathrm{H}+\mathrm{N}$ Session $\mathrm{Q}$.

Möller H., Klatt S. Smelt as host of the sealworm (Pseudoterranova decipiens) in the Elbe estuary. In: Bowen W. D. (ed.). Population biology of sealworm (Pseudoterranova decipiens) in relation to its intermediate and seal hosts. Can. Bull. Fish. Aquat. Sci. 1990. Vol. 22. P. $129-138$.

Moravec F. Parasitic nematodes of freshwater fish of Europe. Praha: Academia, 1994. 473 p.

Nellbring S. The Ecology of Smelts (Genus Osmerus). Nordic J. Freshw. Res. 1989. Vol. 65 P. 116-145.

Obiekezie A. I., Lick R., Kerstan S., Möller H. Larval nematodes in stomach wall granulomas of smelt Osmerus eperlanus from the German North Sea coast. Diseases of Aquatic Organisms. 1992. Vol. 12. P. 177-183.

Palm H. W., Klimpel S., Bucher Ch. Checklist of metazoan fish parasites of German coastal waters Berichte aus dem Institut für meereskunde an der Christian - Albrechts-Universität Kiel. 1999. No. 307. 155 p. D24105 Kiel. Düsternbrooker Weg 20.

Piasecki W., MacKinnon B. M. Life cycle of a sea louse, Caligus elongatus von Nordmann, 1982 (Copepoda, Siphonostomatoida, Caligidae). Canadian Journa of Zoology. 1995. Vol. 73, no. 1. P. 74-82. doi: 10.1139/ z95-009

Scholz T., Hanzelova V. Tapeworms of the genus Proteocephalus Weinland, 1858 (Cestoda: Proteocephalidae), parasites of fishes in Europe. 1998. 118 p.

Scholz T., Marcogliese D. J., Bourque J.-F., Skerikova A., Dodson J. J. Occurrence of Proteocephalus tetrastomus (Rudolphi, 1810) (Cestoda: Proteocephalidea) in Larval Rainbow Smelt (Osmerus mordax) in North America: Identification of a Potential Pathogen Confirmed. J. Parasitol. 2004. 90 (2): 425-427.

Shostak A. W., Dick T. A., Szalai A. J. \& Bernier L. M. J. Morphological variability in Echinorhynchus gadi, E. leidyi, and E. salmonis (Acanthocephala: Echinorhynchidae) from fishes innorthern Canadian waters. Canadian Journal of Zoology. 1986. Vol. 64. P. 985-995.

Sobecka E., Szostakowska B., MacKenzie K., Hemmingsen W., Prajsnar S., Eydal M. Genetic and morphological variation in Echinorhynchus gadi Zoega in Müller, 1776 (Acanthocephala: Echinorhynchidae) from Atlantic cod Gadu morhua L. Journal of Helminthology. 2011. Vol. 86, no. 1. P. 16-25. doi: 10.1017/S0022149X10000891

Sprengel G., Liichtenberg $H$. Infection by endoparasites reduces maximum swimming speed of European smelt Osmerus eperlanus and European eel Anguilla anguilla. Diseases of aquatic organisms. 1991. Vol. 11. P. 31-35.

Sures B. and Knopf K. Parasites as a threat to freshwater eels? Science. 2004. 304. P. 209-211.

Väinölä R., Valtonen E., Gibson D. Molecular systematics in the acanthocephalan genus Echinorhynchus (sensu lato) in northern Europe. Parasitology. 1994. Vol. 108. P. 105-114.

Valtonen E. T., Crompton D. W. T. Acanthocephala in Fish from the Bothnian Bay, Finland. Journal of Zoology. 1990. 220. P. 619-639.

Valtonen E. T., Sirěn T. H., Karvonen A., Pulkkinen K. Suomen Kalojen Loiset. Gaudeamus. 2012. Painopaikka: Tammerprint Oy. Tampere. 540 p.

Vik R. The Diphyllobothrium problem. Journal of Parasitology. 1962. Vol. 52. P. 1-15.

Voigt H. $-R$. A checklist of the parasites on the smelt (Osmerus eperlanus). Särtryck ur Finska VetenskapsSocietetens Parasitologiska institut. Tiedoksianto. Information. 1975. 14. P. 28-40.

Wayland M. T. Morphological variation in Echinorhynchus truttae Schrank, 1788 and the E. bothniensis Zdzitowiecki \& Valtonen, 1987 species complex from freshwater fishes of northern Europe. Biodivers. 2013. Data J. 1: e975. doi: 10.3897/bdj. 1. e975

Wayland M. T., Gibson D. I., Sommerville C. Morphometric discrimination of two allozymically diagnosed sibling species of the Echinorhynchus gadi Zoega in Müller complex (Acanthocephala) in the North Sea. Systematic Parasitology. 2005. 60. P. 139-149.

Wayland M. T., Vainio J. K., Gibson D. I., Herniou E. A., Littlewood D. T. J., Väinölä R. The systematics of Echinorhynchus Zoega in Müller, 1776 (Acanthocephala, Echinorhynchidae) elucidated by nuclear and mitochondrial sequence data from eight European taxa. ZooKeys. 2015. 484. P. 25-52 (26 Feb 2015). doi: 10.3897/zookeys. 484.9132

Willemse J.J. The genus Proteocephalus in the Netherlands. Journal of Helminthology. 1969. Vol. 42. P. 395-410.

Wootten R., Smith J. W. and Needham E. A. 1982 Aspects of the biology of the parasitic copepods Lepeophtheirus salmonis and Caligus elongatus on farmed salmonids, and their treatment. Proceedings of the Royal Society of Edinburgh. Section B. Biological Sciences. 81. P. 185-197. doi: 10.1017/S0269727000003389

Øines $\varnothing$. and P. A. Heuch. Caligus elongatus genotypes on wild and farmed fish. Journal of Fish Diseases. 2007. 30. P. 81-91.

Received April 12, 2017 


\section{СВЕДЕНИЯ ОБ АВТОРАХ:}

\section{Аникиева Лариса Васильевна}

старший научный сотрудник, д. б. н.

Институт биологии Карельского научного центра РАН

ул. Пушкинская, 11, Петрозаводск, Республика Карелия,

Россия, 185910

эл. почта: anikieva@krc.karelia.ru

тел.: (8142) 762706

\section{Иешко Евгений Павлович}

заведующий лабораторией, д. б. н., проф.

Институт биологии Карельского научного центра РАН

ул. Пушкинская, 11, Петрозаводск, Республика Карелия,

Россия, 185910

эл. почта: ieshko@mail.ru

тел.: (8142) 762706

\section{CONTRIBUTORS:}

Anikieva, Larisa

Institute of Biology, Karelian Research Centre,

Russian Academy of Sciences

11 Pushkinskaya St., 185910 Petrozavodsk, Karelia, Russia

e-mail: anikieva@krc.karelia.ru

tel.: (8142) 762706

\section{leshko, Evgeny}

Institute of Biology, Karelian Research Centre,

Russian Academy of Sciences

11 Pushkinskaya St., 185910 Petrozavodsk, Karelia, Russia e-mail: ieshko@mail.ru

tel.: (8142) 762706 